4-1-2009

\title{
The Partially Prudential Doctrine of Mootness
}

Matthew I. Hall

University of Georgia School of Law, matthall@uga.edu

DSPRN

\section{Repository Citation}

Matthew I. Hall, The Partially Prudential Doctrine of Mootness (2009),

Available at: https://digitalcommons.law.uga.edu/fac_artchop/759

This Article is brought to you for free and open access by the Faculty Scholarship at Digital Commons @ University of Georgia School of Law. It has been accepted for inclusion in Scholarly Works by an authorized administrator of Digital Commons @ University of Georgia School of Law. Please share how you have benefited from this access For more information, please contact tstriepe@uga.edu. 


\title{
The Partially Prudential Doctrine of Mootness
}

\author{
Matthew I. Hall* \\ Introduction
}

The law of mootness lacks a coherent theoretical foundation. On the one hand, mootness has been regarded-at least since 1964-as a limitation on federal court jurisdiction, mandated by Article III of the United States Constitution. ${ }^{1}$ Under this account, because mootness is a constitutional, and not merely a prudential, limitation on federal court jurisdiction, it is not waivable, ${ }^{2}$ may be raised at any point in the litigation, ${ }^{3}$ and must be raised by the Court sua sponte where circumstances suggest a possible mootness issue. ${ }^{4}$

* Visiting Assistant Professor of Law, University of the Pacific, McGeorge School of Law; Assistant Professor of Law Designate, University of Georgia School of Law. J.D., cum laude, University of Michigan Law School, 1999. The author is indebted to Ed Cooper, Richard Friedman, Leslie Jacobs, Brad Joondeph, Doug Kahn, Brian Landsberg, Evan Tsen Lee, Thomas Main, Ben Means, Nicole Porter, Lori Ringhand, Christopher Serkin, Michael Shenkman, John Sims, David Skover, Michael Vitiello, and Jarrod Wong for helpful comments on earlier drafts, and to Erica Gilbertson, David F. Levi, Christine Manolakas, and Elizabeth Rindskopf Parker for their support. I also want to thank Andrew Bernick and Olga Serafimova for superb research assistance and James Wirrell and Dragomir Cosanici of the Pacific McGeorge Law Library for their exceptional efforts.

1 See Liner v. Jafco, Inc., 375 U.S. 301, 306 n.3 (1964) (stating in dictum that federal courts lack jurisdiction to hear moot cases because moot cases do not present cases or controversies). Just fifteen years earlier, the same view had been urged in dissent by a lone Justice, protesting the Court's decision to hear an arguably moot case. See Eisler v. United States, 338 U.S. 189, 194 (1949) (Murphy, J., dissenting) ("We can decide only cases or controversies. A moot case is not a "case' within the meaning of Art. III."); cf. St. Pierre v. United States, 319 U.S. 41, 43 (1943) ("[T]he moral stigma of a judgment which no longer affects legal rights does not present a case or controversy for appellate review.").

2 See, e.g., Honig v. Doe, 484 U.S. 305, 317-18 \& n.5 (1988) (considering mootness argument not raised by any party but only by amicus curiae, the United States); Muhammad v. City of N.Y. Dep't of Corr., 126 F.3d 119, 122-24 (2d Cir. 1997); Fox v. Bd. of Trs. of State Univ. of N.Y., 42 F.3d 135, 139-40 (2d Cir. 1994); Bishop v. Comm. on Prof'l Ethics \& Conduct, 686 F.2d 1278, 1284 n.12 (8th Cir. 1982); see also 13A Charles Alan Wright et al., Federal Practice And Procedure $\S 3533.1$ n.35 (2d ed. 1984 \& Supp. 2008).

3 See Honig, 484 U.S. at 317-23 (considering mootness argument raised for the first time at oral argument in the Supreme Court); see also Arizonans for Official English v. Arizona, 520 U.S. 43, 68 n.23 (1997); Seven Words LLC v. Network Solutions, 260 F.3d 1089, 1094 (9th Cir. 2001); In re Smith, 921 F.2d 136, 138 (8th Cir. 1990); Barilla v. Ervin, 886 F.2d 1514, 1519 (9th Cir. 1989); 13A WRIGHT ET AL., supra note 2, § 3533.1 nn.36-37; Sidney A. Diamond, Federal Jurisdiction to Decide Moot Cases, 94 U. PA. L. Rev. 125, 126 (1946).

4 See, e.g., Donovan ex rel. Donovan v. Punxsutawney Area Sch. Bd., 336 F.3d 211, 216 (3d Cir. 2003); Cox v. Phelps Dodge Corp., 43 F.3d 1345, 1347 n.1 (10th Cir. 1994); United States

April 2009 Vol. 77 No. 3 
On the other hand, courts routinely hear moot cases where strong prudential reasons exist to do so-a practice that cannot be reconciled with the belief that mootness is a mandatory jurisdictional bar. Socalled "exceptions" to the doctrine of mootness endow courts with extensive discretion about which moot claims they will dismiss and which they will choose to hear. For example:

- There is a longstanding practice among courts of hearing moot claims, so long as the claim is inherently short-lived and the party asserting the claim also has a reasonable expectation that the asserted wrong could recur. ${ }^{5}$

- Under certain circumstances, federal courts allow plaintiffs with moot claims to avoid dismissal by asserting the rights of nonparties under several ostensibly distinct doctrines that I will refer to collectively as the doctrine of "third-party nonmootness."

- Federal courts have repeatedly declined to dismiss apparently moot claims based on discretionary factors having to do with judicial administration or authority, such as sunk costs on the part of courts, or evidence of gamesmanship by a party in taking action that appears calculated to moot the case.?

Courts and scholars refer to the doctrines under which courts elect to hear moot cases as "exceptions" to the mootness bar, but these exceptions do not "prove the rule"-they debunk it. The exceptions to mootness do not appear to be based on any interpretation of Article III's Case or Controversy Clause ${ }^{8}$ - as they would be if mootness were actually applied as a constitutionally mandated limit on federal court jurisdiction. ${ }^{9}$ Rather, as articulated and applied, they are

v. Johnson, 801 F.2d 597, 600-01 (2d Cir. 1986); see also 13A WRIGHr ET AL., supra note 2, $\S 3533.1 \mathrm{nn} .33$ \& 35; Diamond, supra note 3, at 126 (citing cases).

5 See infra Part II.A.1.

6 See infra Part III.C.

7 See infra Part II.B.4.

8 U.S. Const. art. III, § 2, cl. 1 (extending federal jurisdiction to "all Cases, in Law and Equity, arising under this Constitution, the Laws of the United States, and Treaties made, or which shaii be made, under their Authority;-to all Cases affecting Ambassadors, other public Ministers and Consuls; - to all Cases of admiralty and maritime Jurisdiction;--to Controversies to which the United States shall be a party;--to Controversies between two or more States;-between a State and Citizens of another State;-between Citizens of different States;-between Citizens of the same State claiming Lands under Grants of different States, and between a State, or the Citizens thereof, and foreign States, Citizens or Subjects").

9 For an early argument that the mootness exceptions undermine the common understanding of mootness as a jurisdictional bar, see Honig v. Doe, 484 U.S. 305, 330 (1988) (Rehnquist, C.J., concurring) ("Article III extends the judicial power of the United States only to cases and controversies; it does not except from this requirement other lawsuits which are 'capable of repetition, yet evading review.' If our mootness doctrine were forced upon us by the case or 
based on prudential considerations, such as protection of judicial efficiency and authority, the preference for sufficiently-motivated parties, and avoidance of party gamesmanship. The frequent invocation of these exceptions by federal courts is thus hard to reconcile with the conventional understanding of mootness as a constitutionally mandated jurisdictional bar.

All of this is symptomatic of a deep confusion at the core of the modern understanding of mootness. Mootness doctrine, as currently constituted, does not provide the analytic tools necessary to explain or predict the results in a large number of mootness cases. The doctrine that ostensibly governs mootness decisions does not appear to be driving the analysis, or the results, in the most important subset of mootness cases-those where the result may depend on whether the mootness bar is understood as a prudential or a constitutionally mandated doctrine. ${ }^{10}$ Without waiting for theoretical justification for abandoning the constitutional account, many courts already treat mootness as discretionary in the subset of cases in which there are strong prudential arguments for hearing a case, notwithstanding its mootness.

Scholarly criticism of the mootness doctrine has recognized some of the flaws in the constitutional model, ${ }^{11}$ but it has misdiagnosed the

controversy requirement of Art. III itself, we would have no more power to decide lawsuits which are 'moot' but which also raise questions which are capable of repetition but evading review than we would to decide cases which are 'moot' but raise no such questions.").

10 In a large set of cases, of course, the same result would be reached under either a prudential or a constitutional model of mootness, because the case is apparently moot and there exist no compelling prudential reasons to hear it. I am primarily concerned here with a subset of arguably moot cases: those in which there are good prudential reasons for a court to exercise whatever discretion it may have to hear the case despite its mootness. It is this subset of cases that is pertinent to determining whether courts are applying mootness as a constitutionally mandatory or merely a discretionary doctrine. In such cases, the constitutional account of mootness, even including the established exceptions, would dictate a different result than would a prudential doctrine of mootness. My argument is that in that crucial subset of mootness cases, the treatment of mootness by federal courts is inconsistent with the conventional understanding of mootness as a constitutionally mandated jurisdictional bar. See infra Part II.

11 Fragments of my arguments have appeared in the cases and scholarship, but this Article represents the first sustained defense of the partially prudential paradigm of mootness. For arguments that the constitutional model of mootness is difficult to reconcile with the mootness exceptions, see Honig, 484 U.S. at 330 (Rehnquist, C.J., concurring) (arguing that the exception for cases capable of repetition, yet evading review disproves the notion of mootness as a mandatory jurisdictional doctrine); Evan Tsen Lee, Deconstitutionalizing Justiciability: The Example of Mootness, 105 HARv. L. REv. 603, 623-25 (1992) (arguing that the Supreme Court "suspended" the personal stake requirement in two mootness cases); Robert J. Pushaw, Jr., Justiciability and Separation of Powers: A Neo-Federalist Approach, 81 CoRnell L. Rev. 393, 490 (1996) (stating that the "exceptions" to mootness doctrine are "incomprehensible" if federal 
illness, and so has offered the wrong cure: a purely prudential model of mootness that treats dismissal of any moot case as a matter within the Court's discretion.12 Moreover, neither scholars nor the Court have yet articulated a comprehensive vision of a prudential mootness doctrine that both is theoretically coherent and accords with the manner in which mootness is regularly applied by courts. ${ }^{13}$

This article addresses both the descriptive and normative gaps in the mootness scholarship. I introduce an analytical framework for understanding mootness doctrine that improves on both the constitutional model and prior scholarly reform proposals. Principally, the nature of the mootness bar as constitutional or prudential depends on whether the issue raised by the plaintiff's claim-as opposed to merely the plaintiff's personal stake in that issue-has been rendered moot. I argue that federal courts apply two very different sets of mootness rules in those two kinds of cases. Where the issue itself is moot-that is, where the alleged wrongful conduct is neither ongoing nor reasonably likely to recur as to anyone-the Case or Controversy Clause requires dismissal and prudential concerns have no application. In contrast, when it is only the plaintiff's personal stake that is mootbecause the harm is reasonably likely to recur only as to someone other than the plaintiff-the textual Article III argument for dismissal

courts lack Article III jurisdiction to resolve moot cases); Kristen M. Shults, Friends of the Earth v. Laidlaw Environmental Services: A Resounding Victory for Environmentalists, Its Implications on Future Justiciability Decisions, and Resolutions of Issues on Remand, 89 GEo. L.J. 1001, 1036 (2001) ("[E]xceptions to the personal stake requirement are difficult to understand if mootness is constitutionally required and suggest that the doctrine has been applied more as a matter of discretion.").

12 Several scholars have argued that mootness either always has been, or should be reformulated as, a purely prudential doctrine. See, e.g., Lee, supra note 11, at 654 (proposing that mootness be "plucked of its constitutional plumage"); Pushaw, supra note 11, at 490-93; Shults, supra note 11, at 1033-38.

13 As noted above, several scholars and commentators have taken issue with the notion that mootness is mandated by Article III, but none has articulated a compelling alternative theoretical basis for mootness, much less one that is derived from the policy concerns addressed in existing mootness case law. See, e.g., 13A WRIGHT ET AL., supra note 2, § 3533.1 ("There is reason to wonder whethes mithin icliance should be placed on constimtional concepts of mootness when these concepts are as flexible as they are and all ordinary needs can be met by the discretionary doctrines. The Article III approach is nonetheless firmly entrenched, and must be reckoned the major foundation of current doctrine."); Lee, supra note 11, at 654-68 (attacking constitutional model and describing a proposal for a fully prudential paradigm of mootness); see also Erwin Chemerinsky, A Unified Approach to Justiciability, 22 ConN. L. Rev. 677, 691-94 (1990); Shults, supra note 11, at 1031-38. Further, although the Supreme Court has acknowledged that practical and prudential concerns may warrant hearing a case that would otherwise be considered moot, Friends of the Earth, Inc. v. Laidlaw Envtl. Servs., Inc., 528 U.S. 167, 189-94 (2000); U.S. Parole Comm'n v. Geraghty, 445 U.S. 388, 398-401 (1980), the Court has not yet offered a theory of mootness that can be harmonized with such judicial discretion. 
is far weaker, and consideration of discretionary factors becomes appropriate. I then derive from the case law a number of prudential factors that should-and do-guide courts in the exercise of their discretion whether to dismiss moot claims.

This model offers three principal advantages over both the constitutional model of mootness and prior reform efforts by scholars: (1) it is more theoretically coherent, (2) it better explains current judicial practice in a wider range of mootness cases, and (3) it moves mootness doctrine into closer alignment with related justiciability doctrines, and thus is a step in the direction of a unified theoretical approach to justiciability.

The argument proceeds in three parts. Part I describes the conventional understanding of mootness-as a jurisdictional doctrine mandated by Article III. Part II addresses the theoretical and descriptive shortcomings in the prevailing constitutional model of mootness, and shows the pressing need for a new model adequate to the task of both explaining the results in past cases and providing guidance for future cases. Part III then introduces and defends a new model of mootness, the elements of which are implicit in much of the mootness case law, but which has never been explicitly developed. This new model rests on a critical, but underappreciated, distinction between two types of mootness-the first involving issues that have become moot, and the second involving live issues raised by parties whose personal stake in the issue has become moot. This Part demonstrates that courts often treat issue mootness and personal stake mootness quite differently-invariably dismissing "issue moot" cases while treating as discretionary the decision whether to dismiss "personal stake moot" cases. Part III.B identifies and explains the factors that ought to-and in many cases already do-guide courts in exercising their discretion. Part III.C defends this prudential model of personal stake mootness by analogy to the doctrine of third-party standing - which has always treated as entirely prudential a court's decision whether to permit plaintiffs to establish the justiciability of their claim by reference to the rights of third parties. Part III.D then defends the proposed model of mootness against the charge that it does not go far enoughthat issue mootness, too, should be regarded as prudential rather than constitutional. 


\section{The Conventional Account of Mootness}

\section{A. The Basic Doctrine and the Constitutionalization of Mootness}

Federal courts have long recognized that it is generally undesirable to expend judicial resources hearing cases that cannot alter the affairs of the parties, ${ }^{14}$ or that otherwise have been deprived of vitality by circumstances occurring out of court. ${ }^{15}$ Cases where the litigation concerns an object that has been destroyed or transferred, ${ }^{16}$ for instance, or otherwise seeks relief that cannot be granted, ${ }^{17}$ have routinely been dismissed as moot since the early days of the American republic. ${ }^{18}$

The doctrine of mootness espoused in federal courts today, however, bears very little resemblance to the doctrine as it existed in the nineteenth century. The early doctrine of mootness was generally applied as though it were a discretionary or prudential doctrine. ${ }^{19}$ It was

14 State courts, whose jurisdiction is not, of course, governed by Article III, are similarly reluctant to hear moot cases, but generally treat their mootness doctrines as prudential, and will hear moot cases when the public interest warrants. See, e.g., County of Fresno v. Shelton, 78 Cal. Rptr. 2d 272, 277 (Cal. Ct. App. 1998) (California state courts have discretion to hear moot cases that pose issues of broad public interest that are likely to recur); McBain v. Hamilton County, 744 N.E.2d 984, 987 (Ind. Ct. App. 2001) (Indiana state courts will review moot cases when they present questions of "great public interest that contain issues likely to recur"); Gernstein v. Allen, 630 N.W.2d 672, 676 (Neb. Ct. App. 2001) (Nebraska courts will review moot cases that "involve a matter of great public interest or when other rights or liabilities may be affected by the case's determination"); Cobb v. State Canvassing Bd., 140 P.3d 498, 504 (N.M. 2006) (New Mexico state courts will review moot cases that present issues of substantial public interest or which are capable of repetition, yet evading review); City of Yakima v. Mollett, 63 P.3d 177, 179 (Wash. Ct. App. 2003) (Washington state courts will review moot cases that present "matters of continuing and substantial public interest").

15 See, e.g., United States ex rel. Norwegian Nitrogen Prods. Co. v. U.S. Tariff Comm'n, 274 U.S. 106, 111-12 (1927) (dispute over request for information becomes moot when hearing for which information needed happens); Atherton Mills v. Johnston, 259 U.S. 13, 15-16 (1922) (action contesting validity of child labor statute becomes moot when child at issue reaches age when no longer affected by statute); Berry v. Davis, 242 U.S. 468, 470 (1917) (action to enjoin enforcement of statute becomes moot when statute repealed).

16 See, e.g., Brownlow v. Schwartz, 261 U.S. 216, 217 (1923) (controversy over building becomes moot when building soid to uninvuived thiid party); California v. San Pablo \& Tulare R.R., 149 U.S. 308, 313-14 (1893) (action to recover taxes owed by railroad becomes moot when taxes paid); Nat'l Ass'n of Sec. Dealers v. SEC, 143 F.2d 62, 63 n.1 (3d Cir. 1944) (applicability of regulatory statute to sale of bonds becomes moot when bonds redeemed by obligor).

17 See, e.g., Cheong Ah Moy v. United States, 113 U.S. 216, 217-18 (1885) (dismissing as moot a habeas petition when petitioner had been deported).

18 Diamond, supra note 3, at 132-34 (citing cases).

19 Honig v. Doe, 484 U.S. 305, 330-31 (1988) (Rehnquist, C.J., concurring) (citing Mills v. Green, 189 U.S. 651 (1895)). But see Eisler v. United States, 338 U.S. 189, 194 (1949) (Murphy, J., dissenting) ("We can decide only cases or controversies. A moot case is not a 'case' within the meaning of Art. III."). 
not until 1964 that the Court held for the first time that mootness is a doctrine of constitutional significance. ${ }^{20}$ To understand the flaws in this constitutional model of the mootness doctrine, as well as how that doctrine came into vogue, it will be useful briefly to trace the origins of the doctrine of mootness.

\section{The Original (Nonmandatory) Doctrine of Mootness}

The nineteenth century doctrine of mootness differed in significant respects from the doctrine familiar to modern lawyers. For example, the primary meaning of the term "moot" in American legal usage has undergone significant evolution over the last 100 years. Whereas its early primary meaning was to denote an abstract, hypothetical, or fabricated case-a meaning that endures in our modern use of the term "moot court"-its primary usage today is to refer to a case that has expired, or otherwise has been deprived of vitality by events occurring after the commencement of the action. ${ }^{21}$ Thus, when nineteenth century courts said that they ordinarily would not hear moot cases, they were referring to a broad spectrum of cases in which "there was not at the time a bona fide controversy pending"22-either

20 Liner v. Jafco, Inc., 375 U.S. 301,306 n.3 (1964).

21 There is a long line of authority for the notion that courts should not resolve fabricated cases-that is, cases in which the parties have colluded to present an issue for resolution without the existence of facts raising the issue. See, e.g., United States v. Johnson, 319 U.S. 302, 304-05 (1943) (dismissing case upon discovery that, among other things, plaintiff's counsel was selected by defendant and had never met his client); Lord v. Veazie, 49 U.S. (8 How.) 251, 255 (1850) (dismissing case upon finding that there was "no real conflict between [plaintiff and defendant]; that the plaintiff and defendant ha[d] the same interest, and that interest adverse and in conflict with the interest of third persons, whose rights would be seriously affected if the question of law was decided in the manner that both of the parties to this suit desire it to be"); see also Coxe v. Phillips, (1736) 95 Eng. Rep. 152 (K.B.) (holding that attempt to conduct fictitious action was contempt of court). Although some scholars have found support in these cases for the notion that moot cases are outside the traditional judicial role, see, e.g., Diamond, supra note 3, at 125-26, such reliance is misplaced. First, these historical cases have not held that the resolution of fabricated cases lies beyond federal jurisdiction; they have treated the issue as one of wise use of judicial resources and counsel's duty of candor to the tribunal. Second, a fabricated case is not a "moot" case in the modern sense, as it was never a "live" dispute in the first place. Moreover, there is ample authority for the federal courts' ability to hear and decide collusive cases. See, e.g., Fletcher v. Peck, 10 U.S. (6 Cranch) 87 (1810); Hylton v. United States, 3 U.S. (3 Dall.) 171 (1796)

22 Allen v. Georgia, 166 U.S. 138, 140 (1897); see also Ex parte Steele, 162 F. 694, 701 (N.D. Ala. 1908) (defining a moot case as "one which seeks to get a judgment on a pretended controversy, when in reality there is none, or a decision in advance about a right before it has been actually asserted and contested, or a judgment upon some matter which, when rendered, for any reason, cannot have any practical effect upon a then existing controversy"). 
because one had not yet arisen, or, as we think of it today, because one had arisen and later gone away.

Only this latter meaning remains part of the common modern understanding of mootness. ${ }^{23}$ In contrast, the former would include a range of other circumstances outside the scope of modern mootness doctrine, such as collusive or fabricated cases, in which the parties colluded to bring the case "for the purpose of obtaining the opinion of this court on important constitutional questions without the actual existence of the facts on which such questions can alone arise," ${ }^{24}$ and cases that today would be termed "unripe"-that is, cases challenging an action that had not yet occurred and was not reasonably certain to occur. $^{25}$

Additionally, nineteenth century decisions generally do not indicate that the court lacked authority to hear moot cases. Rather, courts dismissed moot cases using language suggesting an exercise of discretion. ${ }^{26}$ The explanations given for declining to hear moot cases tended to focus not on constitutional text, but on instrumental concerns, such as conservation of judicial resources, ${ }^{27}$ preservation of judicial author-

23 This evolution over time of the meaning of mootness is evident from a comparison of the archaic and more modern definitions provided in Black's Law Dictionary:

moot, adj. 1. Archaic. Open to argument; debatable. 2. Having no practical significance; hypothetical or academic ....

moot, vb. 1. Archaic. To raise or bring forward (a point or question) for discussion.

2. To render (a question) moot or of no practical significance.

Black's Law Dictionary 1029 (8th ed. 2004).

24 Bartemeyer v. Iowa, 85 U.S. (18 Wall.) 129, 134-35 (1873); see also Ex parte Steele, 162 F. at 701 .

25 For instance, in Tregea $v$. Modesto Irrigation District, the court faced a challenge to a statute authorizing an irrigation district to issue bonds. 164 U.S. 179, 185 (1896). The Court found that the district had not yet decided to issue bonds, and held that a determination of the district's authority to issue bonds prior to any attempt by the district to do so would be purely advisory in nature. Id. The Court thus dismissed the case as "moot," although in modern parlance we might call the case unripe. Id; see also Waite v. Dowley, 94 U.S. 527, 534 (1876) (describing case as "moot" where plaintiff asserted claim of third party that was unripe and "may never be raised by any party entitled to raise it"); Smith v. United States, 94 U.S. 97, 97 (1876) ("[W]e are not inclined to hear and decide what may prove to be only a moot case.") (empinasis added).

26 See, e.g., Allen, 166 U.S. at 140 ("[W]e have repeatedly held that we would not hear and determine moot cases.") (emphasis added); Smith, 94 U.S. at 97 ("[W]e are not inclined to hear and decide what may prove to be only a moot case.") (emphasis added).

27 See, e.g., United States v. Johnson, 319 U.S. 302, 305 (1943); Mills v. Green, 159 U.S. 651,653 (1895) ("The defendant moved to dismiss the appeal . . . [arguing] 'that there is now no actual controversy involving real and substantial rights between the parties to the record ....' We are of opinion that the appeal must be dismissed upon this ground, without considering any other question appearing on the record or discussed by counsel."); Waite, 94 U.S. at 534. 
ity, ${ }^{28}$ the desire to ensure that issues are litigated by properly motivated parties, ${ }^{29}$ and the desire to prevent collusive cases. ${ }^{30}$

By the same token, when federal courts in the nineteenth and early twentieth centuries decided to hear apparently moot cases, they also justified those decisions based on practical considerations. ${ }^{31}$ Thus, courts articulated both a general rule that moot cases should be dismissed and a series of exceptions to that general rule to permit consideration of moot cases where compelling reasons existed to hear them. These exceptions, like the rule itself, were justified based on practical considerations of judicial economy, ${ }^{32}$ avoidance of party gamesmanship, ${ }^{33}$ and the desirability of resolving issues that were both substantively important and likely to recur. ${ }^{34}$

28 See, e.g., Johnson, 319 U.S. at 305; Smith, 94 U.S. at 97 (dismissing criminal defendant's appeal from conviction where defendant has refused to subject himself to Court's judgment by escaping from prison); see also, e.g., Walling v. Reuter Co., 321 U.S. 671, 676-77 (1944) (defendant's decision to cease business activities after a court's decision will not deprive court of jurisdiction); Coxe v. Phillips, (1736) 95 Eng. Rep. 152, 152 (K.B.) (holding that attempt to conduct fictitious action was contempt of court).

29 See S. Spring Hill Gold Mining Co. v. Amador Medean Gold Mining Co., 145 U.S. 300 , 301 (1892) (holding that on appeal of action between two corporations that came under control of same person after judgment was rendered in lower court, "litigation has ceased to be between adverse parties, and the case therefore falls within the rule applied where the controversy is not a real one"); Waite, 94 U.S. at 534 ("This court does not sit here to try moot cases to solve a question which may never be raised by any party entitled to raise it."); Lord v. Veazie, 49 U.S. (8 How.) 251, 255 (1850) ("[A]ny attempt, by a mere colorable dispute, to obtain the opinion of the court upon a question of law which a party desires to know for his own interest or his own purposes, when there is no real and substantial controversy between those who appear as adverse parties to the suit, is an abuse which the courts of justice have always reprehended, and treated as a punishable contempt of court.").

30 See, e.g., Bartemeyer v. Iowa, 85 U.S. (18 Wall.) 129, 134-35 (1873).

31 See, e.g., S. Pac. Terminal Co. v. Interstate Commerce Comm'n, 219 U.S. 498, 515-16 (1911); Mills, 159 U.S. at 654 (1895).

32 See, e.g., Smith, 94 U.S. at 97.

33 See, e.g., Mills, 159 U.S. at 653-54 (noting that "if the intervening event is owing either to the plaintiff's own act or to a power beyond the control of either party, the court will stay its hand"). Despite Liner's nominal constitutionalization of mootness, modern courts often focus on the same prudential concerns. See, e.g., City of Erie v. Pap's A.M., 529 U.S. 277, 288 (2000) (noting that the Court's interest "in preventing litigants from attempting to manipulate the Court's jurisdiction to insulate a favorable decision from review further counsels against a finding of mootness here"); Khouzam v. Ashcroft, 361 F.3d 161, 168 (2d Cir. 2004) (holding petition for review by alien not moot after petitioner and government agreed to vacate Board of Immigration Appeals' decision because "[a]t oral argument, we expressed doubts" about the government's position, and the government was apparently "trying to avoid having this Court rule on that issue"); see also infra Part III.B.

34 See, e.g., S. Pac., 219 U.S. at 501; see also, e.g., Grossberg v. Deusebio, 380 F. Supp. 285, 292 (E.D. Va. 1974) (declining to dismiss claim as moot despite fact that plaintiffs "will never again be susceptible to the conduct of which they complained" because hearing claim "is the 
2. The Late-Twentieth Century Recharacterization of Mootness as a Mandatory Jurisdictional Bar

After well over a century of consistent application as a discretionary doctrine, mootness was abruptly transfigured, in early January 1964, into a constitutionally mandated jurisdictional doctrine. The first Supreme Court case explicitly to link Article III with the centuryold doctrine under which courts had frequently dismissed moot claims was Liner v. Jafco, Inc. ${ }^{35}$ In Liner, a contractor sought an injunction prohibiting a labor union from picketing at a construction site. ${ }^{36}$ The state court granted the requested injunction and that decision was affirmed on appeal. ${ }^{37}$ While the union's state court appeal was pending, the construction project was completed. ${ }^{38}$ The state court of appeals affirmed the entry of the injunction on the merits, and also opined that the case was moot because construction had been completed. ${ }^{39}$ On further appeal to the Supreme Court, the respondent contractor contended that the case should be dismissed as moot, and alternatively that the injunction should be affirmed on the merits. ${ }^{40}$

The Supreme Court rejected the argument that the completion of construction mooted the case. The claim was still live, the Court held, because the union sought payment under a bond for the alleged wrongful entry of the injunction..$^{41}$ Thus, the Court held, a decision on the merits would "affect the rights of the litigants," 42 and the claim therefore was not moot. The Court then opined-in a thirty-fourword footnote-that the mootness bar was a jurisdictional rule derived from Article III's Case or Controversy Clause. The relevant footnote reads, in its entirety: "Our lack of jurisdiction to review moot cases derives from the requirement of Article III of the Constitution

only effective means to insure full and deliberate adjudication of the Establishment [Clause] issues").

35 Liner v. Jafco, Inc., 375 U.S. 301, 306 n.3 (1964); see also Eisler v. United States, 338 U.S. 189, 194 (1949) (Murphy, J., dissenting) ("We can decide only cases or controversies. A moot case is not a 'case' within the meaning of Art. III."). This grafting of an Article III rationaic unitu an cxisting doctrine may he seen as part of a larger trend in the mid-twentieth century. See Cass R. Sunstein, What's Standing After Lujan? Of Citizen Suits, "Injuries," and Articie iii,, 91 Mich. L. Rev. 163, 169 (1992) (noting that there appear to have been only eight references to "standing" in Supreme Court cases prior to 1965-and none before 1944).

36 Liner, 375 U.S. at 302.

37 Id. at 303.

38 Id.

39 Id. at 303-04.

40 Id. at 304.

41 Id. at 305.

$42 I d$. at 306 (citing St. Pierre v. United States, 319 U.S. 41, 42 (1943)). 
under which the exercise of judicial power depends upon the existence of a case or controversy." 43

The Court offered no explanation for this novel pronouncement, and cited no case authority in support of its transformation of mootness doctrine into a constitutional requirement derived from Article III's Case or Controversy Clause-and none existed. The sole authority cited consisted of two lightly-reasoned scholarly works that had been published eighteen ${ }^{44}$ and nine ${ }^{45}$ years earlier in the University of Pennsylvania Law Review. Yet the constitutional basis of mootness was far from self-evident. ${ }^{46}$

Had the Court thoroughly considered the rule that it was adopting, it might have pondered whether the putative constitutional linkage would cast doubt on the viability of the longstanding "exceptions" to mootness. The exceptions had been articulated as defining circumstances in which courts would hear cases that were moot-and,

43 Id. at 306 n.3 (citations omitted).

44 See Diamond, supra note 3, at 125-26 (stating, without explanation, that moot cases are not "cases or controversies" within the meaning of Article III). Apart from the conclusory assertion that moot cases are outside of the jurisdictional grant of Article III, the Diamond article simply catalogues different types of cases that have been termed "moot"-such as collusive cases and cases seeking an advisory opinion on a fictitious controversy. See id. at 127-35. Diamond does not explain the basis for the assertion that dismissal of moot cases is mandated by the Constitution, and does not appear to recognize-much less resolve-the tension between the constitutional model and the longstanding prudential exceptions.

45 See Note, Cases Moot on Appeal: A Limit on the Judicial Power, 103 U. PA. L. Rev. 772, 772-73 (1955) (asserting, without historical or textual analysis, that the Case or Controversy Clause deprives federal courts of jurisdiction over moot claims). The Note then proceeds to enumerate various policy reasons why courts should not hear moot cases-none of which has any bearing on the mootness bar's nature as constitutional or prudential. Id. at 773-75. This confusion is evident from the Note's assertion, on the very same page, that on the one hand, "a court is deprived of jurisdiction when a case becomes moot," and on the other that any such limitation is "self imposed," because the Case or Controversy Clause was "probably not intended to set forth jurisdictional limits rigidly." Id. at $772 \& \mathrm{n} .4$ (emphasis added).

46 The notion that the Case or Controversy Clause of Article III requires the plaintiff personally to have suffered injury has itself been questioned. See, e.g., Raoul Berger, Standing to Sue in Public Actions: Is It a Constitutional Requirement?, 78 Y ALE L.J. 816, 827 (1969) (arguing that at the time of the Framing, the Case or Controversy Clause was not understood to require that a party have a personal stake in the outcome of a case in order to bring suit); William A. Fletcher, The Structure of Standing, 98 Y ALE L.J. 221, 229-34 (1988) (arguing that "[p]roperly understood, standing doctrine should not require that a plaintiff have suffered "injury in fact" "); Louis L. Jaffe, Standing to Secure Judicial Review: Public Actions, 74 Harv. L. Rev. 1265, 1269-92 (1961) (questioning the constitutional basis of justiciability doctrine); Steven L. Winter, The Metaphor of Standing and the Problem of Self-Governance, 40 STAN. L. REV. 1371, 1420 (1988) (arguing that pre-twentieth century courts did not view "standing" as a requirement of the Case or Controversy Clause). For further arguments that the Case or Controversy Clause will not bear the weight placed on it by modern justiciability doctrines, see Lee, supra note 11, at 623-25; Shults, supra note 11 , at 1035 . 
as noted above, courts had justified the exceptions based on practical considerations primarily related to efficient judicial administration. But if the mootness bar were mandatory and jurisdictional, as Liner stated, then courts would have no power to hear moot cases, regardless of the benefits of doing so. ${ }^{47}$

Furthermore, Liner's statement that Article III requires dismissal of moot claims was dicta, given that Liner found the claims at issue in that case not to be moot, and declined to dismiss them. ${ }^{48}$ Subsequent cases, however, authored by justices at all points on the political spectrum, followed without question Liner's rationale in holding claims moot and asserting that dismissal of moot claims was constitutionally mandated. ${ }^{49}$ The constitutional basis of the mootness bar swiftly acquired the patina of settled doctrine.

\section{B. The Implications of a Constitutionally Mandated Mootness Doctrine}

Proponents of the constitutional model of mootness long described mootness as being closely related to the doctrine of standing, defining mootness as "the doctrine of standing set in a time frame." Under that formulation, moot cases do not present "cases or controversies" within the meaning of Article III, and thus must be dismissed ${ }^{51}$ just as the claim of a plaintiff who lacks standing has been

47 See infra Part II.A. It was not until twenty-four years later, in Chief Justice Rehnquist's concurrence in Honig, that any member of the Supreme Court acknowledged this tension between the constitutional model of mootness and the discretionary exceptions. Honig v. Doe, 484 U.S. 305, 329-32 (1988) (Rehnquist, C.J., concurring).

48 Liner, 375 U.S. at 306.

49 See, e.g., Lewis v. Cont'l Bank Corp., 494 U.S. 472, 477-78 (1990) (Scalia, J.); Honig, 484 U.S. at 305 (Brennan, J.); Preiser v. Newkirk, 422 U.S. 395, 401-04 (1975) (Burger, C.J.); SEC v. Medical Comm. for Human Rights, 404 U.S. 403 (1972) (Marshall, J.).

50 Henry P. Monaghan, Constitutional Adjudication: The Who and When, 82 YALE L.J. 1363, 1384 (1973). The Supreme Court has repeatedly cited this formulation with approval, see, e.g., Arizonans for Official English v. Arizona, 520 U.S. 43, 68 n.22 (1997); U.S. Parole Comm'n v. Geraghty, 445 U.S. 388,397 (1980), but has more recently recognized that the relationship beiwecin muvotincss and standing is mnre complicated, see Friends of the Earth, Inc. v. Laidlaw Envtl. Servs., 528 U.S. 167, 189-92 (2000) (noting that the "standing in a time frame" formulation does not provide a "comprehensive" explanation of mootness).

51 See Liner, 375 U.S. at 306 n.3; see also Spencer v. Kemna, 523 U.S. 1, 7 (1998) ("This case-or-controversy requirement subsists through all stages of federal judicial proceedings, trial and appellate. ... The parties must continue to have a 'personal stake in the outcome' of the lawsuit.") (citation omitted); Honig, 484 U.S. at 317 ("That the dispute between the parties was very much alive when suit was filed, or at the time the Court of Appeals rendered its judgment, cannot substitute for the actual case or controversy that an exercise of this Court's jurisdiction requires."); id. at 332-33 (Scalia, J., dissenting); Preiser, 422 U.S. at 401 (1975) ("The rule in federal cases is that an actual controversy must be extant at all stages of review, not merely at 


\section{held not to present a case or controversy..$^{52}$}

The corollary to this constitutional understanding of mootness is that courts lack power to create exceptions to the mootness bar. Because the doctrine is a jurisdictional bar mandated by the Constitution, the constitutional text must determine the bounds of the doctrine..$^{53}$

More recently, however, the Supreme Court has begun to distance itself from Professor Monaghan's "standing set in a time frame" formulation, noting that the exceptions to mootness reveal significant differences between that doctrine and standing, ${ }^{54}$ including most notably that, in ruling on mootness, courts may consider a number of factors not derived from the Case or Controversy Clause. ${ }^{55}$ This appears

the time the complaint is filed."); Allen v. Likins, 517 F.2d 532, 534 (8th Cir. 1975) ("It is axiomatic that a 'case' or 'controversy' must exist at all stages of the litigation and not merely at the time the complaint is filed.").

52 Valley Forge Christian Coll. v. Ams. United for Separation of Church \& State, Inc., 454 U.S. 464, 472 (1982) (holding that "Art. III requires the party who invokes the court's authority to 'show that he personally has suffered some actual or threatened injury' ... and that the injury 'fairly can be traced to the challenged action' and 'is likely to be redressed by a favorable decision'") (citations omitted); see also City of L.A. v. Lyons, 461 U.S. 95, 101 (1983) (holding that plaintiff "must demonstrate a personal stake in the outcome in order to assure that concrete adverseness which sharpens the presentation of issues necessary for the proper resolution of constitutional questions").

53 A rule that is mandated by the Constitution may not be made subject to discretionary exceptions. See, e.g., Geraghty, 445 U.S. at 411-12 (Powell, J., dissenting) ("Since the question is one of power, the practical importance of review cannot control .... Nor can the public interest in the resolution of an issue replace the necessary individual interest in the outcome.") (citations omitted); $c f$. Verlinden B.V. v. Cent. Bank of Nig., 461 U.S. 480, 491 (1983) ("This Court's cases firmly establish that Congress may not expand the jurisdiction of the federal courts beyond the bounds established by the Constitution."); 13A WRIGHT ET AL., supra note 2, § 3521 .

The Supreme Court's holding that courts need not always apply the exclusionary rule to statements obtained in violation of a suspect's Miranda rights, see United States v. Patane, 542 U.S. 630 (2004), is not to the contrary. Patane held that the exclusionary rule is not mandated by the Constitution, but rather is only prophylactic-meaning, it is a remedy designed to deter violations of the Constitutional rights of criminal suspects. Id. at 638-40. Because it is merely a prophylactic remedy, it is subject to discretionary exceptions where, for instance, as in Patane, the Court determines that the exception will not undermine the deterrent effect of the rule. Id. Prophylactic rules differ from constitutionally mandated rules in this respect. Id. at 641 .

54 See, e.g., Friends of the Earth, 528 U.S. at 189-91 ("Careful reflection on the long-recognized exceptions to mootness, however, reveals that the description of mootness as 'standing set in a time frame' is not comprehensive .... The plain lesson of these cases is that there are circumstances in which the prospect that a defendant will engage in (or resume) harmful conduct may be too speculative to support standing, but not too speculative to overcome mootness.").

55 See id. at 190-92. Among the discretionary factors that courts may consider are judicial resources expended in consideration of the matter, $i d$. at 191-92, the effect of the decision on third parties, Trachtman v. Anker, 563 F.2d 512, 514 n.1 (2d Cir. 1977), and whether dismissal would undermine judicial authority, City of Erie v. Pap's A.M., 529 U.S. 277, 288 (2000) ("Our interest in preventing litigants from attempting to manipulate the Court's jurisdiction to insulate 
to reflect a growing awareness on the Court's part that the constitutional model of mootness fails to account for the full array of relevant considerations. Nonetheless, the Court still regards mootness as being derived from Article III, and as reflecting Article III concerns. ${ }^{56}$

\section{The Constitutional Model of Mootness Is Fundamentally Flawed}

The constitutional model of mootness suffers from two related flaws, one theoretical-the doctrine is internally inconsistent-and the other descriptive - it fails to account for the results in many actual mootness cases. The constitutional model of mootness doctrine posits a constitutionally mandated rule requiring dismissal of moot cases. Yet current doctrine subjects that rule to numerous discretionary exceptions that cannot be derived from the constitutional text, and that existed long before the constitutional model came into fashion. This presents a serious problem because a jurisdictional limitation imposed by the Constitution cannot be made subordinate to judge-made common law exceptions, no matter how sensible or necessary those exceptions may appear. This Part argues that if the mootness bar were truly a mandatory, jurisdictional rule imposed by the Constitution, then the exceptions for cases capable of repetition, yet evading review, for class actions, and for voluntary cessation could not exist.

This theoretical flaw is compounded by the descriptive problem because in practice, courts routinely stretch the exceptions beyond their doctrinal limits, and thereby expand the set of moot cases that can be heard in federal court. Part II.A argues that the established exceptions to mootness cannot be reconciled with the constitutional model of mootness. Part II.B argues that, without regard for the nominal requirements of mootness doctrine, and despite the prevalence of constitutional rhetoric in mootness decisions, federal courts addressing contentions of mootness in the most pertinent category of cases frequently treat mootness as a discretionary matter, and are guided by prudential factors, rather than by any understanding of Article III's Case or Controversy Clause.

\footnotetext{
a favorable decision from review further counsels against a finding of mootness here."); Schaefer v. Townsend, 215 F.3d 1031, 1033 (9th Cir. 1990) ("If [election law] cases were rendered moot by the occurrence of an election, many constitutionally suspect election laws . . could never reach appellate review." (quoting Joyner v. Mofford, 706 F.2d 1523, 1527 (9th Cir. 1983))) (alterations in original).

56 Friends of the Earth, 528 U.S. at 180 (stating that the Case or Controversy Clause "underpins" mootness doctrine).
} 


\section{A. The Constitutional Model of Mootness Is Internally Inconsistent}

The premise at the core of post-1964 mootness jurisprudence is that dismissal of moot cases is mandated by Article III's Case or Controversy Clause. ${ }^{57}$ And yet several well-established components of modern mootness doctrine are fundamentally inconsistent with that proposition. These include the three principal "exceptions" to mootness, which permit courts to hear moot claims where (1) the claim raises issues that are capable of repetition, yet evading review, (2) the mootness was effected by defendant's voluntary cessation of the challenged activity, or (3) the moot claim is asserted by someone purporting to represent a Rule 23 class, some members of which have nonmoot claims. These exceptions generally long predate Liner's statement that Article III mandates the dismissal of moot cases, and they cannot readily be reconciled with it.

\section{The Prudential Nature of the Mootness Exceptions}

The strict application of a rule that federal courts should not hear or decide moot cases would entail certain inefficiencies and other costs. The three most frequently-applied exceptions to mootness doctrine-those applying to (1) claims "capable of repetition, yet evading review"-that is, claims that raise issues that are of inherently short duration, and are likely to recur; ${ }^{58}$ (2) cases mooted by the defendant's voluntary cessation of the challenged activity; ${ }^{59}$ and (3) class actions in which the named plaintiff's claim has become moot ${ }^{60}$ - each evolved to accommodate a specific concern or set of concerns that would be raised by a uniform policy requiring dismissal of all moot claims. ${ }^{61}$

57 DeFunis v. Odegaard, 416 U.S. 312, 316 (1974) (per curiam) ("The inability of the federal judiciary to review moot cases derives from the requirement of Art. III of the Constitution under which the exercise of judicial power depends upon the existence of a case or controversy.") (citation omitted); see also 13A WRIGHT ET AL., supra note 2, § 3533.1 ("There is reason to wonder whether much reliance should be placed on constitutional concepts of mootness when these concepts are as flexible as they are and all ordinary needs can be met by the discretionary doctrines. The Article III approach is nonetheless firmly entrenched, and must be reckoned the major foundation of current doctrine.").

58 See, e.g., Honig v. Doe, 484 U.S. 305, 317-18 (1988); S. Pac. Terminal Co. v. Interstate Commerce Comm'n, 219 U.S. 498, 515 (1911); cf. Weinstein v. Bradford, 423 U.S. 147, 149 (1975) (per curiam).

59 See, e.g., Friends of the Earth, 528 U.S. at 189; City of Mesquite v. Aladdin's Castle, Inc., 455 U.S. 283, 289 (1982); United States v. W.T. Grant Co., 345 U.S. 629, 632 (1953); Mills v. Green, 159 U.S. 651,654 (1895).

60 See, e.g., U.S. Parole Comm'n v. Geraghty, 445 U.S. 388, 398-99 (1980); Gerstein v. Pugh, 420 U.S. 103, 110-11 n.11 (1975); Sosna v. Iowa, 419 U.S. 393, 402-03 \& n.11 (1975).

61 I do not discuss here the fourth recognized "exception" to the mootness bar, which is qualitatively different from the three discussed herein. The "collateral consequences" exception 
The exceptions, in other words, evolved in accordance with a set of prudential concerns that are implicit-and occasionally explicit-in the case law.

Notably absent from the seminal cases for each exception is any indication of concern for the Court's authority to create prudential exceptions to the mootness bar. ${ }^{62}$ These cases have made no effort to justify the exceptions by reference to the Case or Controversy Clause. Rather, they evince an assumption that the Court possessed such authority-an assumption that belies the view that mootness has jurisdictional significance or is mandated by the Case or Controversy Clause. The exceptions are explicitly based on prudential concerns, most of which bear no evident relation to the Case or Controversy Clause. ${ }^{63}$

\section{a. The Problem of Inherently Short-Lived Cases}

One problem that would arise from the strict application of a rule that courts should dismiss cases that have become moot is that certain claims-those that are ordinarily of very short duration-would thereby be immunized from judicial review entirely. Plainly, this result would be undesirable, ${ }^{64}$ and the exception for claims that are ca-

holds that an appeal from a criminal conviction is not mooted by the defendant's completion of incarceration or probation because the fact of the conviction will have ongoing collateral consequences on other aspects of the plaintiff's life-such as his or her ability to register to vote or to secure employment. See, e.g., Fiswick v. United States, 329 U.S. 211, 222 (1946) (holding that where collateral consequences exist, the defendant "has a substantial stake in the judgment of conviction which survives the satisfaction of the sentence imposed on him.") Strictly speaking, then, the collateral consequences exception is not an exception at all. Rather than permitting courts to hear a moot claim, as the other exceptions do, it rests on the fact that the defendant's claim of wrongful conviction is not moot at all, because the defendant is still suffering harm, and the Court's judgment could therefore benefit the defendant. See id.

62 See, e.g., Sosna, 419 U.S. at 401; W.T. Grant Co., 345 U.S. at 632; S. Pac., 219 U.S. at 514-16; Mills, 159 U.S. at 654.

63 See infra Part II.A.1.a-c. (discussing prudential origins of the mootness exceptions). Few of the prudential factors that courts consider are arguably relevant to or derived from the Case or Controversy Clause. See infra Part III.B.1 (discussing "justiciability factors"). Thus, ahihuiugh the policiss embodied in Article III's Case or Controversy Clause may be relevant even to the analysis of "personal stake" mootness, they are but one of several factors, and their relevance is attenuated and may yield to the other factors. See, e.g., Honig, 484 U.S. at 331 (Rehnquist, C.J., concurring) ("[W]hile an unwillingness to decide moot cases may be connected to the case or controversy requirement of Art. III, it is an attenuated connection that may be overridden where there are strong reasons to override it.").

64 See, e.g., Roe v. Wade, 410 U.S. 113, 125 (1973) ("But when, as here, pregnancy is a significant fact in the litigation, the normal 266-day human gestation period is so short that the pregnancy will come to term before the usual appellate process is complete. If that termination makes a case moot, pregnancy litigation seldom will survive much beyond the trial stage, and appellate review will be effectively denied. Our law should not be that rigid."); see also, e.g., 
pable of repetition, yet evading review, responds to this problem by permitting review of moot cases that raise issues that are likely to recur and are so inherently short-lived that each occurrence is likely to be rendered moot before review can be completed. ${ }^{65}$

The capable-of-repetition exception arose very early in the history of the mootness doctrine, in the 1911 case of Southern Pacific Terminal Co. v. Interstate Commerce Commission. ${ }^{66}$ Southern Pacific involved a challenge to an order of the Interstate Commerce Commission ("ICC") requiring the owner of a shipping terminal to cease providing a particular shipper with preferential rates that were not conferred upon others. ${ }^{67} \mathrm{By}$ its own terms, the ICC order was to expire after two years, and it had expired before the railroad's appeal reached the Supreme Court. ${ }^{68}$

The ICC contended that the action had therefore become moot, but the Court denied a motion to dismiss for two reasons. First, the Court stated that "the order of the Commission may to some extent (the exact extent it is unnecessary to define) be the basis of further proceedings." 69 Second, the court stated that there was a "broader consideration":

The questions involved in the orders of the Interstate Commerce Commission are usually continuing (as are manifestly those in the case at bar) and their consideration ought not to be, as they might be, defeated, by short term orders, capable of repetition, yet evading review, and at one time the Government and at another time the carriers have their rights determined by the Commission without a chance of redress. ${ }^{70}$

Corrigan v. City of Newaygo, 55 F.3d 1211, 1214 (6th Cir. 1995) ("To hold this case moot would require the absurd result that a court would never be able to rule on the [city] ordinance .... [T] he town could repeatedly apply the ordinance to different candidates, none of whom could ever challenge it in court."). Of course, if the dismissal of moot cases were truly mandated by the Case or Controversy Clause, then undesirable results would present no basis for disregarding the constitutional limitation on federal court authority. See, e.g., Honig, 484 U.S. at 329-32 (Rehnquist, C.J., concurring); Geraghty, 445 U.S. at 411 (Powell, J., dissenting) ("Since the question is one of power, the practical importance of review cannot control.").

65 See, e.g., Geraghty, 445 U.S. at 398.

66 S. Pac. Terminal Co. v. Interstate Commerce Comm'n, 219 U.S. 498 (1911). Although the doctrine had been applied in earlier cases, Southern Pacific coined the phrase "capable of repetition, yet evading review." See 13A WRIGHT ET AL., supra note 2 , § 3533.8 .

67 See S. Pac., 219 U.S. at 514.

68 Id.

$69 \mathrm{Id}$. at 515 .

70 Id. 
Southern Pacific has been cited frequently and followed consistently in the ninety-eight years since it was decided. As commonly articulated in modern decisions, the capable of repetition, yet evading review exception applies in circumstances where "(1) the challenged action was in its duration too short to be fully litigated prior to its cessation or expiration, and (2) there was a reasonable expectation that the same complaining party would be subjected to the same action again." 71

The classic modern application of the capable-of-repetition exception is in an abortion case, such as Roe v. Wade. ${ }^{72}$ A plaintiff's challenge to a restriction on her right to obtain an abortion is inherently short-lived, and will always be rendered moot by events-either by birth or by termination of the pregnancy-prior to completion of appellate review. ${ }^{73}$ Thus, unless an exception were applied, the conventional doctrine would require that a court dismiss the case as moot. ${ }^{74}$ As discussed more fully below, however, courts in such cases routinely ignore the second requirement, that there be a reasonable expectation that the same complaining party will again be subjected to the same action. Courts simply apply the capable-of-repetition exception without inquiring as to any expectation of recurrence on the part of the plaintiff. ${ }^{75}$ Indeed, federal courts, including the Supreme Court,

71 Wis. Dept. of Indus. v. Gould, Inc., 475 U.S. 282, 285 n.3 (1986) (expiration of threeyear order debarring plaintiff from contracting with the state did not moot appeal); SEC $v$. Sloan, 436 U.S. 103, 108-10 (1978) (expiration of SEC orders suspending trading of corporation's common stock did not moot case); Weinstein v. Bradford, 423 U.S. 147, 149 (1975); Cerro Wire \& Cable Co. v. FERC, 677 F.2d 124, 127 n.2 (D.C. Cir. 1982) (expiration of certificates to transport natural gas issued by Federal Energy Regulatory Commission did not moot claim); see also 13A WRIGHT ET AL., supra note $2, \S 3533.8$ ("Courts confronting discontinued or expired official acts frequently deny mootness on the ground that the acts are "capable of repetition, yet evading review." ).

Although Southern Pacific dealt with short term regulatory orders of an administrative agency, and many cases applying the exception involve challenges to administrative orders of short duration, the exception has been applied in a far broader range of circumstances. See People for the Ethical Treatment of Animals, Inc. v. Gittens, 396 F.3d 416, 422 (D.C. Cir. 2005) ("Later cases speak not of orders, but of repetition of the "controversy." ") (citations omitted); see also, e.g., SEC v. Okin, 132 F.2d 784, 787 (2d Cir. 1943) (applying exception to actions of an officer of a private company).

72 Roe v. Wade, 410 U.S. 113 (1973).

73 See, e.g., id. at 125 ("[T] he normal 266-day human gestation period is so short that the pregnancy will come to term before the usual appellate process is complete.").

74 See, e.g., Weinstein, 423 U.S. at 149 (holding that capable-of-repetition exception applies only where likelihood of recurrence is shown as to plaintiff); Van Wie v. Pataki, 267 F.3d 109, 113-14 (2d Cir. 2001) (same).

75 See infra Part II.B.2; see also, e.g., Honig v. Doe, 484 U.S. 305, 335-36 (1988) (Scalia, J., dissenting) (stating that Roe and some election law cases dispense with the same party requirement "entirely" and focus instead "upon the great likelihood that the issue will recur between the 
have repeatedly applied the exception where likely recurrence was shown only as to other members of the public at large. ${ }^{76}$

\section{b. The Problem of Insincere Reform}

Another problem that would follow from the uniform application of a rule requiring dismissal of moot claims is that it would empower defendants unilaterally to eliminate federal jurisdiction by temporary reform. Where defendant's own actions have mooted the plaintiff's claim for relief, courts have naturally been quite reluctant to deny judicial review, in part because of the concern that defendant's "reform" may be fleeting or insincere, and that the challenged behavior will resume after the action has been dismissed. ${ }^{77}$ Thus, federal courts have long greeted with skepticism assertions of mootness based on defendant's voluntary discontinuance of the challenged conduct. ${ }^{78}$

Although this doctrine has been a part of mootness case law since the nineteenth century, ${ }^{79}$ the 1953 case of United States v. W.T. Grant $C o$. provides a classic, and oft-cited, formulation of what has come to

defendant and other members of the public at large without ever reaching [the Court]"); Roe, 410 U.S. at 125 ("Pregnancy provides a classic justification for a conclusion of mootness. It truly could be 'capable of repetition' yet evading review."); Cruz v. Farquharson, 252 F.3d 530, 534 n.4 (1st Cir. 2001) (noting that the Court in Roe arguably diluted the same party requirement since it never inquired as to whether there was an expectation that Roe herself might become pregnant again and commenting that "[i]n the abstract, this might be an interesting subject for a law review article").

76 See infra Part II.B.2; see also, e.g., Roe, 410 U.S. at 125 (declining to dismiss moot claim and noting certainty of recurrence as to others); Doe v. Bolton, 410 U.S. 179, 187 (1973) (following Roe in declining to dismiss abortion case despite termination of pregnancy before appeal); Rosario v. Rockefeller, 410 U.S. 752,756 n.5 (1973) (declining to dismiss challenge to durational residency requirement for voting, despite plaintiff's current ability to vote, because of likelihood of recurrence as to other voters); Dunn v. Blumstein, 405 U.S. 330, 333 n.2 (1972) (same).

77 See, e.g., Friends of the Earth, Inc. v. Laidlaw Envtl. Servs., S28 U.S. 167, 189-90 (2000) (defendant's voluntary compliance with mercury discharge limits did not moot action injunction absent showing that violations could not reasonably be expected to recur); United States v. W.T. Grant Co., 345 U.S. 629, 632 (1953) (If courts are deprived of jurisdiction from defendant's own actions, "[t]he defendant is free to return to his old ways. This, together with a public interest in having the legality of the practices settled, militates against a mootness conclusion." (citation omitted)).

78 See, e.g., City of Mesquite v. Aladdin's Castle, Inc., 455 U.S. 283, 289 (1982) ("It is well settled that a defendant's voluntary cessation of a challenged practice does not deprive a federal court of its power to determine the legality of the practice."); W.T. Grant Co., 345 U.S. at 632 ("[V]oluntary cessation of allegedly illegal conduct does not deprive the tribunal of power to hear and determine the case, i.e., does not make the case moot."); Walling v. Helmerich \& Payne, Inc., 323 U.S. 37, 43 (1944) ("Voluntary discontinuance of an alleged illegal activity does not operate to remove a case from the ambit of judicial power); see also 13A WRIGHT ET AL., supra note 2 , § 3533.8 .

79 See, e.g., Mills v. Green, 159 U.S. 651, 654 (1895). 
be called the "voluntary cessation" exception to mootness. ${ }^{80}$ In Grant, the United States sued to enforce the Clayton Act's prohibition on interlocking corporate directorates against a Mr. Hancock, who served on the boards of several corporations that were competitors in the retail industry. ${ }^{81}$ Soon after the action was filed, Hancock resigned from the relevant corporate boards. ${ }^{82}$ The district court then granted motions for summary judgment by all defendants, finding that "there is not 'the slightest threat that the defendants will attempt any future activity in violation of Section 8 [if they have violated it already].' "83

The Supreme Court rejected the argument that defendants' voluntary cessation of the challenged action rendered the case moot, and held that "[a] controversy may remain to be settled" 84 in circumstances where the defendant has voluntarily ceased allegedly illegal conduct, in part because "the defendant is free to return to his old ways," 85 and in part because there may be a "public interest in having the legality of the practices settled." 86

Following this rationale, federal courts routinely have declined to dismiss as moot cases in which the mootness was the result of defendant's discontinuance of the challenged conduct. ${ }^{87}$ The rule is that "a

80 United States v. W.T. Grant Co., 345 U.S. 629 (1953).

81 Id. at 630 . The applicable section of the Clayton Act is section 8, which prohibits any person from serving as a director or officer of two or more corporations if such corporations are "by virtue of their business and location of operation, competitors, so that the elimination of competition by agreement between them would constitute a violation of any of the antitrust laws." 38 Stat. 730 (1914) (codified with slightly different language at 15 U.S.C. $\$ 19$ (2006)).

82 W.T. Grant Co., 345 U.S. at 630.

83 Id. at 630-31 (quoting United States v. W.T. Grant Co., 112 F. Supp. 336, 338 (S.D.N.Y. 1952)) (bracketed language in both lower court and Supreme Court opinions).

84 Id. at 632; see also id. at $632 \mathrm{n.5}$ ("It is the duty of the courts to beware of efforts to defeat injunctive relief by protestations of repentance and reform, especially when abandonment seems timed to anticipate suit, and there is probability of resumption." (quoting United States v. Or. State Med. Soc'y, 343 U.S. 326, 333 (1952))).

$85 \mathrm{Id}$.

86 Id. Federal courts have occasionally relied on the public interest in the relief sought as a basis for retaining jurisdiction over an arguably moot case. See, e.g., S. Pac. Terminal Co. v. Interstate Commerce Comm'n, 219 U.S. 498, 516 (1911); United States v. Trans-Missouri Freight Ass'n, 166 U.S. 290, 309 (1897); Walling v. Haile Gold Mines, Inc., 136 F.2d 102, 105-06 (4th Cir. 1943); Otis \& Co. v. SEC, 106 F.2d 579, 583-84 (6th Cir. 1939); Boise City Irrigation \& Land Co. v. Clark, 131 F. 415, 419 (9th Cir. 1904). Some scholarly advocates of the constitutional model of mootness have recognized the obvious tension between these holdings and the conception of mootness as jurisdictional, see, e.g., Diamond, supra note 3, at 138 ("[T]his principle should have no bearing on the jurisdictional issue."), but have made no effort to harmonize their conception of mootness with the contradictory case law, see id.

87 13A WRIGHT ET AL., supra note 2 , § 3533.8 . 
defendant's voluntary cessation of a challenged practice does not deprive a federal court of its power to determine the legality of the practice," 88 because of the likelihood of recurrence of the challenged conduct. ${ }^{89}$ These policy concerns have led the Court to lay out a "stringent" standard that places a "heavy burden [on the party claiming mootness] of persuading the court that the challenged conduct cannot reasonably be expected to start up again." 90 Yet the Court could only do so if mootness was a matter of prudential concern, rather than a jurisdictional bar.

\section{c. The Problem of Third Party Recurrence}

Alone among the major exceptions to mootness doctrine, the class action exception was first created after Liner's reframing of mootness as a mandatory jurisdictional doctrine. The class action exception attempts to fill a gap in the capable of repetition, yet evading

88 Friends of the Earth, Inc. v. Laidlaw Envtl. Servs., Inc., 528 U.S. 167, 189 (2000) (quoting City of Mesquite v. Aladdin's Castle, Inc., 455 U.S. 283, 289 (1982)).

89 Any evidence supporting an inference of likely resumption of the challenged activity has historically weighed against dismissing the case as moot. See, e.g., United States v. W.T. Grant Co., 345 U.S. 629, 632 (rejecting contention of mootness where defendant had ceased challenged activity, because "the defendant [would be] free to return to his old ways"); Walling v. Helmerich \& Payne, Inc., 323 U.S. 37, 43 (1944) (holding case not moot where respondent continued to assert the legality of the challenged conduct but discontinued the conduct); Goshen Mfg. Co. v. Hubert A. Myers Mfg. Co., 242 U.S. 202, 207-08 (1916) (same); see also Helmerich \& Payne, Inc., 323 U.S. at 42-43 (timing of defendant's voluntary cessation after start of litigation held to support court's refusal to dismiss as moot); FTC v. Goodyear Tire \& Rubber Co., 304 U.S. 257, 260 (1938) (holding FTC order to cease and desist certain conduct remained reviewable despite later amendment to statute prohibiting challenged activity and respondent's resulting discontinuation of the conduct). This history does not fit well with the constitutional model, however. The relevance of evidence supporting a likelihood of recurrence is clear under a prudential model of mootness - the more likely the claim is to recur and be litigated again, the more sensible it is to hear it now, for reasons including judicial economy, the public interest in resolution of important legal questions, etc. See infra Part III.B (identifying various prudential factors). But the relevance of such evidence is less obvious under a constitutional model of mootness.

90 Friends of the Earth, 528 U.S. at 189. Before dismissing a claim on mootness grounds based on defendant's voluntary cessation of the challenged conduct, a federal court must be "absolutely clear" that the challenged conduct is not reasonably likely to recur. Id. Unlike the class action and "capable of repetition, yet evading review" exceptions, which simply permit courts to hear certain moot cases in spite of their mootness, one could argue that application of the voluntary cessation "exception" amounts to a determination that the case is not moot at allbased on the idea that the object of most injunction actions is to secure not merely defendant's cessation of the challenged action, but also a court order enjoining its resumption. See, e.g., Trans-Missouri, 166 U.S. at 309 (holding case not moot despite defendant's voluntary cessation of challenged activity because relief sought included court order enjoining resumption); see also supra note 61 (discussing collateral consequences exception). The role of likely recurrence of an expired wrong in the mootness analysis is discussed in Part II.B. 
review exception-namely, that certain inherently short-lived claims are unlikely to recur as to the named plaintiff, but are likely, or even certain, to recur as to others.

The exception was first articulated by the Supreme Court in 1975 in Sosna v. Iowa. ${ }^{91}$ Sosna arose out of a divorce action filed by an Iowa resident just one month after she moved to Iowa..$^{92}$ Iowa law contained a one-year durational residency requirement for invoking its divorce jurisdiction..$^{93}$ After her divorce action was dismissed, the plaintiff filed a federal class action challenging the durational residency requirement as unconstitutional. ${ }^{94}$ By the time the case reached the Supreme Court, she had satisfied the one-year residency requirement and had obtained a divorce in a different state-both of which plainly rendered her personal claim moot. ${ }^{95}$

Despite the fact that the named plaintiff's personal claim had become moot, the Supreme Court declined to dismiss the action, holding that strict application of the mootness bar to inherently short-lived claims would be inappropriate because it would prevent such claims from ever being adjudicated:

A blanket rule under which a class action challenge to a short durational residency requirement would be dismissed upon the intervening mootness of the named representative's dispute would permit a significant class of federal claims to remain unredressed for want of a spokesman who could retain a personal adversary position throughout the course of the litigation. ${ }^{96}$

The claim would, in other words, evade review. If this rationale sounds familiar, it is because it is nearly identical to the rationale offered in cases applying the "capable of repetition, yet evading review" exception. The class action exception, as articulated in Sosna, might best be understood as an expansion of the capable-of-repetition exception to permit federal courts to review claims that are capable of repetition as to other class members, irrespective of whether they are also capable of repetition as to the named plaintiff. ${ }^{97}$

91 Sosna v. Iowa, 419 U.S. 393 (1975).

92 Id. at 395.

93 Id.

94 Id. at 395-96; Sosna v. Iowa, 360 F. Supp. 1182, 1183 (N.D. Iowa 1973).

95 Sosna, 419 U.S. at 399.

96 Id. at $401 \mathrm{n} .9$.

97 See id. at 401; see also infra Part III.C (discussing these doctrines under the rubric of "third party non-mootness"). But see Franks v. Bowman Transp. Co., 424 U.S. 747, 754 (1976) ("[N]othing in [Sosna] ... holds or even intimates that the fact that the named plaintiff no longer 
The Court then held that the "live controversy" required by Article III need not exist between plaintiff and defendant, but may exist between defendant and a member of the class. ${ }^{98}$ The Supreme Court has justified the class action exception in terms of the desirability of ensuring that judicial review is available for claims that raise issues of importance, ${ }^{99}$ and the policy against empowering defendants to procure mootness in order to avoid adjudication. ${ }^{100}$ Thus, the concerns that underlie the class action exception to the mootness doctrine appear to mirror those that underlay the exceptions for capable of repetition, yet evading review and voluntary cessation.

Notably, the cases that created each of the three exceptions discussed above-as well as later cases applying them-reveal little or no concern with whether the courts had authority to create exceptions to the general rule favoring dismissal of moot cases. Rather, they all appear simply to assume that courts have authority to decide moot cases where persuasive reasons exist to do so. They appear, in other words, to assume dismissal of moot cases is largely a matter of judicial discretion. The courts' continuing treatment of mootness as "flexible" where personal stake is concerned reveals that this attitude has survived the Court's formal constitutionalization of mootness doctrine. Moreover, as discussed in Part II.B, the "exceptions" are applied far more broadly than their doctrine would indicate, and in a manner which is entirely inconsistent with the notion that mootness is a constitutionally mandated limitation on federal court jurisdiction.

\section{The Existence of Prudential Exceptions Disproves the Constitutional Model}

Application of any of the mootness exceptions discussed above entails a determination that, although the case is moot, the court may hear it nonetheless. ${ }^{101}$ But if the mootness bar were really jurisdictional in nature, courts would have no authority to hear moot cases, even where prudential factors favored hearing the case. A jurisdic-

has a personal stake in the outcome of a certified class action renders the class action moot unless there remains an issue 'capable of repetition, yet evading review."').

98 Sosna, 419 U.S. at 402.

99 Id. at 401 n.9.

100 U.S. Parole Comm'n v. Geraghty, 445 U.S. 388, 400-04 (1980); Deposit Guar. Nat'l Bank v. Roper, 445 U.S. 326, 340 (1980); Gerstein v. Pugh, 420 U.S. 103, 110 n.11 (1975); Susman v. Lincoln Am. Corp., 587 F.2d 866, 870 (7th Cir. 1978).

101 See Erwin Chemerinsky, Federal Jurisdiction $\$ 2.5$ (making this point as to mootness exceptions generally), 2.5.3 (capable of repetition, yet evading review), 2.5.5 (class action exception) (4th ed. 2003). 
tional rule, in other words, may not be made subordinate to prudential exceptions that are not derived from the relevant constitutional text. ${ }^{102}$

Of course many constitutional rules have "exceptions," which do not disprove the constitutional nature of the underlying rule. The critical distinction is between exceptions that are derived from the pertinent constitutional provision and those that are not. Analytically, an "exception" that is derived from the relevant constitutional provision is not an exception, so much as it is part of the fabric of the constitutional rule. It delineates the boundaries of that rule. ${ }^{103}$ In contrast, an exception that is not derived from the relevant constitutional text, but is justified solely based on pragmatic considerations external to the constitutional provision-such as efficient use of judicial resources, or the effect on absent individuals who face obstacles to assertion of their own rights-is accurately described as an "exception." The application of such exceptions undermines the assertedly constitutional nature of the underlying rule. The routine practice among federal courts of applying prudential exceptions to mootness, with no effort to link them to the Case or Controversy Clause of Article III, thus reveals that mootness is not being treated as a jurisdictional doctrine.

Chief Justice Rehnquist offered an early argument for the tension between the constitutional model and the prudential nature of the mootness exceptions in his often-overlooked concurrence in Honig $v$. Doe:

If our mootness doctrine were forced upon us by the case or controversy requirement of Art. III itself, we would have no

102 Honig v. Doe, 484 U.S. 305, 329-32 (1988) (Rehnquist, C.J., concurring); Geraghty, 445 U.S. at 411 (Powell, J., dissenting) ("Since the question is one of power, the practical importance of review cannot control."); see also Budinich v. Becton Dickinson \& Co., 486 U.S. 196, 203 (1988) (stating that where a jurisdictional rule was not satisfied, "Court of Appeals was without jurisdiction to review the merits"); Chemerinsky, supra note 13, at 692 ("If mootness is an article III requirement, then how can the Court create broad exceptions based on the desire to facilitate judicial review ... ?"); 13A WRIGHT ET AL., supra note 2, $\$ 33521$ (discussing authority holding purported expansions of federal jurisdiction beyond limits of Art. III to be impermissible), 3533.1 ("There is reason to wonder whether much reliance should be placed on constitutional concepts of mootness when these concepts are as flexible as they are and all ordinary needs can be met by the discretionary doctrines. The Article III approach is nonetheless firmly entrenched, and must be reckoned the major foundation of current doctrine.").

103 A helpful illustration can be found in the collateral consequences "exception" to mootness, which I discuss above, in note 61. The collateral consequences "exception" is, according to the distinction I am defending, part of the mootness rule rather than an exception to it, which is to say: a case is not actually moot if the exception applies (in this instance, because the plaintiff is still suffering harm from the fact of his or her earlier criminal conviction). See CHEMERINSKY, supra note $101, \S 2.5 .2$. 
more power to decide lawsuits which are "moot" but which also raise questions which are capable of repetition but evading review than we would to decide cases which are "moot" but raise no such questions. ${ }^{104}$

The plaintiffs in Honig were disabled students who sued a school district alleging that the district's disciplinary actions against them violated the reasonable accommodation provisions of the Education of the Handicapped Act (the "Act"). ${ }^{105}$ The Act covers disabled children between the ages of 3 and 21, a fact which led the Court to dismiss as moot the claims of one respondent, who was 24 years of age at the time the case was decided. 106 The other respondent, Smith, was 20 years of age, and thus still covered by the Act. Smith's claims were evidently moot, however, as he was not facing any proposed disciplinary proceedings, and was no longer enrolled in school in the defendant school district. Nor was there a reasonable likelihood of repetition as to Smith, because he no longer even resided in the petitioner school district. Yet the Court applied the capable of repetition, yet evading review exception and declined to dismiss Smith's claims for injunctive relief. ${ }^{107}$

Chief Justice Rehnquist concurred in the majority's opinion, and also wrote separately to explain his reservations about the constitutional model of mootness. As Rehnquist explained, if Liner were correct that the general rule favoring dismissal of moot cases is jurisdictional and mandated by the Constitution, then courts would lack authority to hear and decide moot cases even if prudential factors strongly favored hearing the claim. ${ }^{108}$

Rehnquist also argued that the roots of the capable of repetition, yet evading review exception were plainly pragmatic in nature, and unrelated to the text of the Case or Controversy Clause. ${ }^{109}$ Indeed, Rehnquist wrote, the only logical conclusion that could be drawn from

104 Honig, 484 U.S. at 330 (Rehnquist, C.J., concurring).

105 See id. at 308; see also Education of the Handicapped Act, Pub. L. No. 91-230, 84 Stat. 175 (1970) (codified as amended in scattered sections of 20 U.S.C. $\$ \S 1400-1482$ (2006)).

106 Honig, 484 U.S. at 318.

107 Id. The Court acknowledged that respondent Smith was not at the time of decision even enrolled in any public school, that he had not asserted any intention to re-enroll, and that he was just three months from his 21 st birthday, at which time he would no longer be covered by the Act. Id. at 318-19 \& n.6. The Court nonetheless found that Smith's claims were capable of repetition, yet evading review. Id. at 319-20.

108 See id., 484 U.S. at 330 (Rehnquist, C.J., concurring); see also U.S. Parole Comm'n v. Geraghty, 445 U.S. 388, 411 (1980) (Powell, J., dissenting) ("Since the question is one of power, the practical importance of review cannot control.").

109 Honig, 484 U.S. at 330-31 (noting that the exception was initially adopted "in the light 
the history of the development of mootness doctrine is that, while Article III concerns may animate mootness doctrine in some way, mootness is fundamentally a prudential doctrine. ${ }^{110}$ Rehnquist cited the capable of repetition, yet evading review and voluntary cessation exceptions as examples of circumstances where sufficient reason existed to override the Article III concerns that animate the mootness bar. ${ }^{111}$ Given the force of his criticism of the constitutional model, it is perhaps odd that Rehnquist's proposed solution was exceedingly incremental-he proposed only a new exception for cases mooted while pending before the Supreme Court.112

The criticism of mootness doctrine as theoretically incoherent would hardly set it apart from the other justiciability doctrines, such as standing and ripeness, many aspects of which have been similarly criticized. ${ }^{113}$ A second critique of the conventional account of mootness, however, is perhaps more damaging: that in the subset of mootness cases in which the prudential and constitutional models of mootness would dictate different results, ${ }^{114}$ the current doctrine has little explanatory power. That is to say: the doctrine fails to account for the results

of obvious pragmatic considerations, with no mention of Art. III as the principle underlying the mootness doctrine").

110 See id. at 331 ("[W]hile an unwillingness to decide moot cases may be connected to the case or controversy requirement of Art. III, it is an attenuated connection that may be overridden where there are strong reasons to override it.").

111 Id. at 331-32. More recent scholarship has expanded upon Chief Justice Rehnquist's argument and offered a more thorough critique of the constitutional model of mootness. Professor Lee's important article, for instance, mounts a persuasive normative argument against the constitutional account of mootness, and argues that mootness doctrine should be reformulated in its entirety to "operate on a prudential basis." Lee, supra note 11 , at 609 . While I tend to agree with most of Professor Lee's normative and historical arguments, I differ with his description of the case law and his prescription for reform. First, I believe his argument that "the Court should transform mootness from a constitutional doctrine into a prudential doctrine," see id. at 605 , fails to recognize the degree to which mootness already operates as a prudential doctrine. See infra Parts II.B, III.B. Second, I argue below that the arguments for the "deconstitutionalization of mootness" that have been raised by critics of the constitutional model apply exclusively (or almost exclusively) to personal stake mootness. See infra Part III.D. Third, and perhaps most imporiaui, there is a significant practical advantage to my more incremental approach: because my partially prudential model of mootness is based on a reconciliation of tensions in the existing case law, rather than a proposed transformation of the doctrine, my approach can be adopted by lower federal courts without need to await further authority from the Supreme Court. See infra Part III.D.

112 Honig, 484 U.S. at 332 (proposing "an additional exception to our present mootness doctrine for those cases where the events which render the case moot have supervened since our grant of certiorari").

113 See supra note 46; see also Chemerinsky, supra note 13; Pushaw, supra note 11.

114 This would be the case, for instance, in cases in which the claim is arguably moot but a strong argument can be made for hearing it on prudential grounds. 
in a wide range of actual cases because courts in those cases appear to be following a model of mootness that not only finds no explanation in the Liner model, ${ }^{115}$ but also is flatly at odds with it.

\section{B. The Constitutional Model Is Descriptively Inaccurate}

Despite the prevalence in mootness cases of rhetoric suggesting that courts are treating mootness as a constitutionally mandated jurisdictional bar, the reasoning and results in a wide range of mootness cases cannot be explained by the constitutional model, but rather are consistent only with a prudential model of mootness. A close examination of the mootness cases reveals that conventional mootness doctrine does not account for the factors that courts actually apply in determining whether to dismiss claims as moot, and thus fails utterly to explain the results in a wide range of mootness cases. Rather than simply applying the doctrine underlying each exception, courts, including the Supreme Court, have frequently bent the doctrine to enable them to hear even more moot cases.

This Subpart explores the manner in which courts have distorted the nominal elements of each of the mootness exceptions in order to expand the circumstances under which they can hear moot cases, and concludes that the evident pattern of routine departures from the nominally governing doctrine indicates that mootness decisions are frequently driven by prudential factors. ${ }^{116}$ It bears emphasizing again that, as discussed above, the mootness exceptions are themselves incompatible with an Article III analysis. The courts' relaxation of the so-called "requirements" of these flawed "exceptions" so as to hear an

115 See supra Part I.A.2.

116 See, e.g., City of Erie v. Pap's A.M., 529 U.S. 277, 287-89 (2000) (reciting that justiciability is a threshold question of jurisdiction but declining to dismiss based on "[o]ur interest in preventing litigants from attempting to manipulate the Court's jurisdiction to insulate a favorable decision from review"); U.S. Parole Comm'n v. Geraghty, 445 U.S. 388, 395-407 (1980) (reciting that dismissal of moot cases is mandated by the Constitution but declining to dismiss moot case because of likelihood of recurrence as to others in class); Rosario v. Rockefeller, 410 U.S. 752,756 n.5 (1973) (citing Dunn v. Blumstein, 405 U.S. 330 (1972), in support of holding that "[a]lthough . . . petitioners will be eligible to vote in the next scheduled New York primary, this case is not moot, since the question the petitioners raise is 'capable of repetition, yet evading review" "); Roe v. Wade, 410 U.S. 113, 125 (1973) (reciting that dismissal of moot cases is usually required by Article III's Case and Controversy Clause, but declining to dismiss moot claim based on certainty of recurrence as to others); Dunn v. Blumstein, 405 U.S. 330, 333 n.2 (1972) (approving lower court's treatment of mootness and stating that "[a]lthough appellee now can vote, the problem to voters posed by the Tennessee residence requirements is capable of repetition yet evading review"). 
even larger group of otherwise moot cases reveals the prudential nature of the doctrine.

\section{The Pertinent Subset of Cases}

As an initial matter, it is worthwhile to define the subset of mootness cases that is most capable of illuminating the nature of the mootness bar. In most cases, both a constitutional and a prudential rule will dictate the same result: either dismissal (because the claim is moot and no compelling prudential reasons exist to hear it) or nondismissal (because the claim is not moot at all). Thus any discussion of the constitutional or prudential nature of the mootness bar in such cases is arguably dicta, inasmuch as it is not pertinent to the result. ${ }^{117}$ The critical subset of cases for purposes of analyzing whether courts treat mootness as jurisdictional or prudential is that set of cases in which a claim is moot but there exist powerful prudential arguments in favor of hearing the case.

In such cases, because a prudential rule would likely dictate a different result than a constitutional rule, the reasoning and decision of the court help illuminate whether federal courts are actually applying mootness as a constitutional or a prudential doctrine. There are of course exceptions, but frequently, when prudential factors strongly favor hearing a moot claim, courts find a way to hear the claim, even at the expense of distorting the doctrine. Thus, the oft-remarked inconsistency among mootness cases can be seen as an indication that, where strong prudential reasons exist to hear a case, courts relax the ostensible doctrinal requirements in order to hear the case-as only a prudential model of mootness would permit. In close cases, courts often treat mootness as prudential.

\section{Judicial Distortion of the Capable of Repetition, Yet Evading Review Exception}

The ostensible prerequisites for application of the exception for cases "capable of repetition, yet evading review" are that: "(1) the challenged action was in its duration too short to be fuily litigaied prior to its cessation or expiration, and (2) there was a reasonable expectation that the same complaining party would be subjected to the same action again."118 The reality, however, is quite different.

117 See infra Part III.D.

118 Weinstein v. Bradford, 423 U.S. 147, 149 (1975) (per curiam). Although the version of the capable of repetition, yet evading review exception set forth in Weinstein ostensibly has two requirements, an influential commentator has observed that it can be broken down further into 
Courts commonly-even routinely-relax each of the nominal requirements and hear moot cases where the challenged action is not necessarily short-lived, ${ }^{119}$ and even where there is no reasonable expectation that the same party would again be subjected to the same action.

Although the "requirement" that the same complaining party will be harmed by recurrence of the challenged action appears to a be a bright-line rule-and has frequently been cited as such by courts declining to apply the "capable of repetition, yet evading review" exception ${ }^{120}$ - courts have nonetheless frequently disregarded this so-called "requirement" and held claims not to be moot despite the lack of any reasonable likelihood that the same complaining party would again be subject to the same action. ${ }^{121}$

three separate elements: first, that the official acts that provoked the litigation are reasonably likely to recur; second, that the same plaintiff will be affected by such repetition; and third, that effective remedies could not be provided in the event of repetition (in other words, the issue evades review). 13A WRIGHT ET AL., supra note $2, \S 3533.8$.

119 Although it is routinely discussed as part of the "capable of repetition" exception, no one seriously contends that the "yet evading review" portion is constitutionally mandated. Even Justice Scalia-the sitting Justice most adamant in his defense of the Liner constitutional model of mootness, see, e.g., Pap's A.M., 529 U.S. at 305-06 (Scalia, J., concurring in part and concurring in the judgment) ("[W]e have no power to suspend the fundamental precepts that federal courts are limited by the case-or-controversy requirement of Art. III to adjudication of actual disputes between adverse parties, and that this limitation applies at all stages of review.") (internal citations and quotations omitted); Friends of the Earth, Inc. v. Laidlaw Envtl. Servs., Inc., 528 U.S. 167, 212 (2000) (Scalia, J., dissenting) ("We have repeatedly recognized that what is required for litigation to continue is essentially identical to what is required for litigation to begin: There must be a justiciable case or controversy as required by Article III."); Honig v. Doe, 484 U.S. 305, 341 (1988) (Scalia, J., dissenting) ("[T]he probability of recurrence between the same parties is essential to our jurisdiction as a court ....")-has conceded that "the 'yet evading review' portion of our 'capable of repetition, yet evading review' test is prudential; whether or not that criterion is met, a justiciable controversy exists," Honig, 484 U.S. at 341; see also, e.g., Clark v. Brewer, 776 F.2d 226, 229 (8th Cir. 1985) (holding that proper inquiry is not into whether the particular challenged activity would evade review, but into whether claim is of a sort that would typically evade review); Nat'I Wildlife Fed'n v. Costle, 629 F.2d 118, 123-24 n.19 (D.C. Cir. 1980) (rejecting argument that order with three year duration is too long to permit application of exception).

120 See, e.g., DeFunis v. Odegaard, 416 U.S. 312, 316 (1974) (holding plaintiff's challenge to denial of entry into law school moot when plaintiff was in final year of school despite "great public interest in the continuing issues" raised on appeal); Laurenzo v. Miss. High Sch. Activities Ass'n, 662 F.2d 1117, 1120-21 (5th Cir. 1981) (dismissing as moot plaintiff's challenge to exclusion from high school athletics and refusing to apply capable-of-repetition exception based on likelihood of recurrence as to plaintiff's younger siblings); Gomes v. R.I. Interscholastic League, 604 F.2d 733, 736 (1st Cir. 1979) (refusing to hold that question presented was capable of repetition as to other high school students after original plaintiff graduated).

121 See, e.g., Roe v. Wade, 410 U.S. 113, 125 (1973) (finding challenge to abortion law not moot after plaintiff no longer pregnant and noting that "[p]regnancy often comes more than once to the same woman, and in the general population, if man is to survive, it will always be with 
One type of such a claim, which predictably becomes moot before litigation can be concluded and is not likely to recur as to the same plaintiff, is a claim challenging a state durational residency requirement. A durational residency requirement is a statutory provision that conditions access to some privilege or benefit of state citizenship-such as voting, ${ }^{122}$ social welfare benefits, ${ }^{123}$ or state employment ${ }^{124}$ - on residency in the state for some particular period of time. Because the requisite period of time is generally short, any one plaintiff's claim will invariably be mooted by the passage of time before the completion of appellate review. ${ }^{125}$ And yet the orthodox capable of repetition, yet evading review exception would not save the claim from mootness, because a durational residency requirement is highly unlikely to be applied repeatedly to the same plaintiff-once an individual has satisfied the residency requirement, it would not again be applied to her unless she later: (1) established residency outside the state, (2) subsequently moved back into the state, and (3) thereafter again sought access to the privilege or benefit in question.

us" (emphasis added)); Dunn, 405 U.S. at 333 n.2 (1972) (noting that "[a]lthough appellee now can vote, the problem to voters posed by the Tennessee residence requirements is capable of repetition, yet evading review"); Cruz v. Farquharson, 252 F.3d 530, 534 n.4 (1st Cir. 2001) (noting that the Court in Roe arguably diluted the same party requirement since it never inquired as to whether there was an expectation that Roe herself might become pregnant again and mentioning "[i]n the abstract, this might be an interesting subject for a law review article"); Schaefer v. Townsend, 215 F.3d 1031, 1033 (9th Cir. 2000) (holding plaintiff's challenge to eligibility requirements to run for political office not moot after election passed, although plaintiff did not allege an intention to run for office again); Corrigan v. City of Newaygo, 55 F.3d 1211, 1213-14 (6th Cir. 1995) (holding a challenge to eligibility requirements for city government not moot after election passed because to hold the "case moot would require the absurd result that a court would never be able to rule on the [city] ordinance [and would allow] . . . [t] he town [to] repeatedly apply the ordinance to different candidates, none of whom could ever challenge it in court").

122 See, e.g., Dunn, 405 U.S. at 332 n.1 (twelve month state residency and three month county residency required to be eligible to vote); Hall v. Beals, 396 U.S. 45, $46 \mathrm{n} .1$ (1969) (per curiam) (six month state residency, ninety day county or city residency, and fifteen day precinct residency required to he eligible to vote).

123 See, e.g., Shapiro v. Thompson, 394 U.S. 618, 624 n.3 (1969) (one-year durational residency requirement to qualify for full state welfare benefits); Roe v. Anderson, 134 F.3d 1400, 1402 n.2 (9th Cir. 1998) (same).

124 See, e.g., Walsh v. City and County of Honolulu, 460 F. Supp. 2d 1207, 1209 (D. Haw. 2006) (state residency required at time of application to be eligible for employment); Nehring v. Ariyoshi, 443 F. Supp. 228, 229 (D. Haw. 1977) (three-year durational residency requirement for government employment).

125 Indeed, if courts enforced a strict rule of dismissal of moot cases, states would be able to evade judicial review of their durational residency requirements simply by providing a sufficiently brief required term of residency. 
Because this combination of events is ordinarily both highly speculative and exceedingly unlikely to occur, courts are unable to find a "reasonable likelihood" that the challenged conduct will recur as to the same plaintiff. ${ }^{126}$ One would therefore expect courts to find the capable-of-repetition exception inapplicable, and to dismiss the claim as moot. And yet quite frequently, the result is just the opposite: in cases where the prudential factors line up in favor of hearing the case, frequently courts will simply relax the same-plaintiff requirement and apply the capable-of-repetition exception based on a likelihood of recurrence as to others. ${ }^{127}$

A 1972 case involving voting rights-Dunn v. Blumstein-exemplifies this phenomenon. ${ }^{128}$ Dunn concerned a constitutional challenge to Tennessee's durational residency requirement for registering to vote. ${ }^{129}$ The plaintiff (and respondent), James Blumstein, moved to Tennessee on June 12, 1970, to begin employment as an Assistant Professor of Law at Vanderbilt University. ${ }^{130}$ Desiring to vote in the upcoming August and November elections, he attempted to register on July $1,1970 .{ }^{131}$ His application was rejected, however, on the ground that Tennessee law authorized registration only for persons who-at the time of the next election-would have been residents of the state for a full year, and of their county for three months. ${ }^{132}$ A three-judge district court held the durational residency requirement unconstitutional, and the Supreme Court affirmed. ${ }^{133}$

Under conventional doctrine, Professor Blumstein's claims appeared to be moot: the Supreme Court opinion in Blumstein was issued more than twenty months after Blumstein took up residency in Tennessee, and at a time when he had plainly satisfied both the three month and one year state residency requirements. Nor could his claim be found to be "capable of repetition" under conventional doctrine, as there was no suggestion that Blumstein himself might move out of state and establish residency, and then return, or otherwise again be

126 See, e.g., Hall, 396 U.S. at 49-50 (referring to such a scenario as "speculative contingencies [that] afford no basis for our passing on the substantive issues the appellants would have us decide").

127 See, e.g., Storer v. Brown, 415 U.S. 724, 737 n.8 (1974) (finding case not moot based on likelihood of recurrence as to others); Rosario v. Rockefeller, 410 U.S. 752, 756 n.5 (1973) (same); Dunn, 405 U.S. at 333 n.2 (same).

128 Dunn v. Blumstein, 405 U.S. 330 (1972).

129 Id. at 331-32 \& n.1.

130 Id. at 331.

131 Id.

132 Id.

133 Id. at $332-33$. 
subjected to the durational residency requirements. Thus, there was nothing to support a finding that the plaintiff had a reasonable likelihood of again suffering the same alleged deprivation. ${ }^{134}$

The Supreme Court, however, quickly dispensed with the apparent mootness of Blumstein's claims. The Court affirmed as proper the district court's rejection of the state's mootness argument, and held that the claim was "capable of repetition, yet evading review," 135 because "[a]lthough [Blumstein] now can vote, the problem to voters posed by the Tennessee residence requirements is 'capable of repetition, yet evading review' ... . [because] the laws in question remain on the books . ..."136 The Court, in short, simply substituted ongoing harm to Tennessee voters, coupled with likely recurrence as to other Tennessee voters, for the purported "requirement" that the moot claim be shown to be capable of repetition as to the plaintiff. ${ }^{137}$

\section{Judicial Modification of the Class Action Exception}

The evolution of the class action exception over the past thirty years provides another instance of the steady march of case law away from the constitutional model of mootness doctrine. Although Article III had, since Liner, been held to require that the case or controversy that must exist at the outset of the action must also persist through all stages of appellate review, the Court in Sosna effectively dispensed with this requirement, holding that the mootness of the named plaintiff's claim will not require dismissal-so long as absent members of the class plaintiff seeks to represent have nonmoot claims. ${ }^{138}$ In Sosna, the Court held that the controversy remained very much alive for the class of persons appellant had been certified to represent because new residents of Iowa were being affected by the enforcement of the allegedly unconstitutional statute..$^{139}$

134 See Weinstein v. Bradford, 423 U.S. 147, 149 (1975) (per curiam).

135 Dunn, 405 U.S. at 333 n.2.

136 Id. (emphasis added) (internal citations omitted)

137 The Supreme Court has applied a similar rationale in numerous other cases in the area of voting rights law and elsewhere. See, e.g., Storer v. Brown, 415 U.S. 724 (1974); Kosario v. Rockefeller, 410 U.S. 752 (1973).

138 Sosna v. Iowa, 419 U.S. 393, 402 (1975) ("The controversy may exist . . between a named defendant and a member of the class represented by the named plaintiff, even though the claim of the named plaintiff has become moot." (emphasis added)). Sosna also stated that the named plaintiff had to possess a live claim at the time the complaint was filed, and at the time class certification was granted. Id.

139 Id. at 401 . One thing that is notable from this rationale is that it depends on a congressional conferral of judicial authority (via enactment of Federal Rule of Civil Procedure 23) to hear claims of absent class members. But Congress cannot grant jurisdiction to federal courts 
The opinion in Sosna expressed two limits on the rule in that case, both of which were subsequently abandoned in fairly short order. First, the Court attempted to cabin the exception by limiting it to circumstances in which class certification had been granted before the named plaintiff's claim was rendered moot. ${ }^{140}$ At the same time, the opinion left the door open for a broader exception by stating, in footnote 11 , that:

There may be cases in which the controversy involving the named plaintiff is such that it becomes moot as to them before the district court can reasonably be expected to rule on a certification motion. In such instances, whether the certification can be said to 'relate back' to the filing of the complaint may depend upon the circumstances of the particular case and especially the reality of the claim that otherwise the issue would evade review. ${ }^{141}$

The second limitation that Sosna articulated was that the exception would not apply unless the issue would otherwise evade review: " $[\mathrm{T}]$ he same exigency that justifies this doctrine serves to identify its limits. In cases in which the alleged harm would not dissipate during the normal time required for resolution of the controversy," (i.e., where "the issue sought to be litigated [would not] escape[] full appellate review at the behest of any single challenger"), "the general principles of Art. III jurisdiction require that the plaintiff's personal stake in the litigation continue throughout the entirety of the litigation." 142

These attempts to limit the breadth of Sosna's class action exception have been systematically ratcheted back by subsequent decisions. The same year that it decided Sosna, the Court in Gerstein v. Pugh ${ }^{143}$ walked through the door left open by Sosna's footnote 11 and dispensed once and for all with the requirement that class certification be granted before the named plaintiff's claim became moot. ${ }^{144}$ Gerstein

over anything other than a case or controversy. See Verlinden B.V. v. Cent. Bank of Nig., 461 U.S. 480, 491 (1983) ("This Court's cases firmly establish that Congress may not expand the jurisdiction of the federal courts beyond the bounds established by the Constitution."); see also 13A WRIGHT ET AL., supra note 2, § 3521. Thus, if Congress has the authority to empower courts to hear class claims even where the named plaintiff's own claim is moot, then there can be nothing in the Case or Controversy Clause limiting federal jurisdiction to situations where the plaintiff has a live claim.

140 See Sosna, 419 U.S. at 402.

141 Id. at 402 n.11.

142 Id. at $401-02$.

143 Gerstein v. Pugh, 420 U.S. 103 (1975).

144 See id. at 110 n.11. 
involved a Fourth Amendment challenge to a Florida statute permitting any noncapital offense to be charged by information, without a judicial determination of probable cause. ${ }^{145}$ Individuals so charged "could be detained for a substantial period solely on the decision of a prosecutor." 146 Two detainees filed a class action under 42 U.S.C. $\$ 1983$ challenging this scheme as violative of their Fourth Amendment rights. ${ }^{147}$ The plaintiffs' pretrial detention had apparently terminated before class certification was granted, which-under the constitutional model of mootness-would ordinarily result in dismissal of their claims as moot. ${ }^{148}$ The Court, however, declined to dismiss the case as moot, holding that it belonged

to that narrow class of cases in which the termination of a class representative's claim does not moot the claims of the unnamed members of the class .... [because] [p]retrial detention is by nature temporary, and it is most unlikely that any given individual could have his constitutional claim decided on appeal before he is either released or convicted. The individual could nonetheless suffer repeated deprivations, and it is certain that other persons similarly situated will be detained under the allegedly unconstitutional procedures. The claim, in short, is one that is distinctly "capable of repetition, yet evading review." 149

Thus, the combination of a speculative possibility that a named plaintiff could again be arrested and held in pretrial detention, together with the certainty that others will suffer deprivations under the same procedures, suffices to satisfy the "capable of repetition" prong of the exception..$^{150}$ As in Dunn, the certainty of recurrence as to others was found to suffice in lieu of likely recurrence as to the named plaintiff. Although the opinion in Gerstein recites that mootness is a constitutional matter, the Court's decision effectively suspends the personal stake requirement, ${ }^{151}$ based on prudential concerns about the

145 See id. at 105-07.

146 Id. at 106.

147 Id. at $106-07$.

148 Id. at $111 \mathrm{n} .11$ ("[T]he record does not indicate whether any of them were still in custody awaiting trial when the District Court certified the class. Such a showing ordinarily would be required to avoid mootness under Sosna. But this case is a suitable exception to that requirement.").

149 Id. at $110 \mathrm{n} .11$ (emphasis added) (citation omitted).

$150 \mathrm{Id}$. at $111 \mathrm{n} .11$ ("It is by no means certain that any given individual, named as plaintiff, would be in pretrial custody long enough for a district judge to certify the class. Moreover, in this case the constant existence of a class of persons suffering the deprivation is certain.").

151 Although the Court asserted that the plaintiff "could" suffer a repeated deprivation, 
importance of the issues and their likely-indeed, certainrecurrence.

\section{Judicial Distortion of the Voluntary Cessation Exception}

As noted above, federal courts have long greeted with skepticism assertions of mootness based on defendant's voluntary discontinuance of the challenged conduct. ${ }^{152}$ This venerable doctrine is not easily harmonized with the more recent constitutional model of mootness. Courts in voluntary cessation cases openly consider prudential and practical concerns that have no bearing on the case or controversy question, such as the public interest in having an issue resolved, ${ }^{153}$ sunk costs in litigating the issue to date, ${ }^{154}$ and the importance of avoiding party manipulation of federal jurisdiction. ${ }^{155}$

Just as with the capable of repetition and class action exceptions, courts often apply voluntary cessation to justify hearing cases that they wish to hear for prudential reasons. Take, for example, the Supreme Court's treatment of voluntary cessation in City of Erie v. Pap's A.M. ${ }^{156}$ In Pap's, the plaintiff operated a nude dancing establishment and sued the city of Erie, Pennsylvania, seeking an injunction against enforcement of an ordinance that banned public nudity. ${ }^{157}$ The trial court granted the injunction on federal constitutional grounds, and the state Supreme Court affirmed that decision. ${ }^{158}$ While the City's petition for certiorari was pending, the seventy-two year old man who

this is precisely the sort of speculative possibility that the Court-in cases lacking the strong prudential arguments for hearing the case-has dismissed as inadequate. See, e.g., Hall v. Beals, 396 U.S. 45, 49-50 (1969) ("[S]uch speculative contingencies afford no basis for our passing on the substantive issues the appellants would have us decide . . .."); cf. Lee, supra note 11, at 624-26 (characterizing Roe v. Wade and Geraghty as "instance[s] in which the Court in effect suspended the personal stake requirement").

152 See supra Part II.A.

153 See, e.g., United States v. W.T. Grant Co., 345 U.S. 629, 632 (1953) (holding that the reasons to hear a case despite defendant's voluntary cessation include the "public interest in having the legality of the practices settled").

154 See, e.g., Friends of the Earth, Inc. v. Laidlaw Envtl. Servs., 528 U.S. 167, 191-92 (2000).

155 See, e.g., City of Erie v. Pap's A.M., 529 U.S. 277, 288 (2000); Khouzam v. Ashcroft, 361 F.3d 161, 167-68 (2d Cir. 2004) (rejecting contention of mootness based on government's agreement to vacatur, based on evidence that government was seeking to avoid court ruling on issue of public importance); Albers v. Eli Lilly \& Co., 354 F.3d 644, 646 (7th Cir. 2004) (refusing to dismiss claim on petitioner's motion, stating: "One good reason to exercise discretion against dismissal is to curtail strategic behavior. . . We think it best . . . to carry through so that . . an attempt to make the stock of precedent look more favorable than it really is may be foiled.").

156 City of Erie v. Pap's A.M., 529 U.S. 277 (2000).

157 ld. at 284-85.

158 Id. 
owned the plaintiff corporation chose to retire. ${ }^{159} \mathrm{He}$ submitted a sworn declaration stating that he had exited the adult entertainment business, closed the Kandyland club that was the subject of the litigation, and sold the real estate on which it was located. ${ }^{160} \mathrm{He}$ therefore moved to dismiss the case as moot. ${ }^{161}$

The Court denied the motion, found the case not moot, and reversed on the merits. ${ }^{162}$ The Court described the mootness issue as a "close" one, but found that the case was not moot because (1) Pap's could resume its nude dancing operations at some point in the future, and (2) the City (the defendant below) was suffering harm in the form of the state court's order invalidating its public nudity ordinance. ${ }^{163}$ Neither of these rationales, of course, fits readily into the traditional voluntary cessation doctrine. That doctrine has been applied where (1) the defendant ceases engaging in the challenged action, in a way that arguably moots the claim, but (2) the court finds it reasonable to expect the challenged action to recur. ${ }^{164}$ The Court's opinion in Pap's turns this doctrine on its head, applying voluntary cessation in a situation utterly divorced from its usual context and rationale: It was the plaintiff who had changed course, thereby mooting his own claim, and the challenged action-defendant's enforcement of its ordinancewas certain not to recur absent court action (because it had been enjoined by the state court).

The Court's first rationale - that Pap's could resume its activities despite the retired owner's sworn statement that he did not intend to do so-is unpersuasive as a mootness analysis. The Court cited no opinion in which a case had been deemed nonmoot despite the plaintiff's desire to abandon his claim for relief. Concurring in part, ${ }^{165} \mathrm{Jus}-$ tice Scalia referred to this part of the Court's rationale as "the neat trick of identifying a 'case or controversy' that has only one interested party." 166 Justice O'Connor's opinion for the majority appears to rest on a desire to protect the Court's authority against party manipulation

159 Id. at 288.

100 ia. ai $287-\mathrm{oog}$.

161 Id. at 287.

162 Id. at 283.

163 Id. at $288-89$.

164 13A WRIGHT ET AL., supra note 2, § 3533.5.

165 Justice Scalia concurred as to the Court's merits opinion and its judgment of reversal, but not its mootness analysis. Pap's A.M., 529 U.S. at 307 (Scalia, J., concurring in part and concurring in the judgment). His concurrence in the judgment is curious, to say the least, given that he believed the case was moot and thus-supposedly-outside the Court's Article III jurisdiction. See id. at 302, 307.

$166 I d$. at 307 . In terms of the traditional rationale for justiciability doctrines, there was, of 
that is intended to destroy jurisdiction. ${ }^{167}$ This is a legitimate prudential concern, to be sure, but one that is not evidently derived from any interpretation of the Case or Controversy Clause-which makes no distinction between moot cases rendered moot by party manipulation and those rendered moot by other causes.

The Court's second rationale-that the case was saved from mootness by the ongoing harm suffered by the City in the form of an arguably incorrect merits opinion by the state courts ${ }^{168}$-is no more persuasive. Any injunction entails the harm to the defendant of having to comply with an arguably incorrect merits opinion. If the Court's analysis were correct, then no injunctive relief claim could ever become moot if the plaintiff prevailed below and secured an injunction, so long as the defendant wished to challenge the injunction. Moreover, the argument again ignores the plaintiff's sworn assertion that he lacked any interest in the outcome of the litigation. ${ }^{169}$

The cases in which courts apply the most common mootness exceptions reveal a troubling disconnect between mootness doctrine and mootness practice. When faced with cases presenting strong prudential reasons for adjudication, the Court has regularly distorted or revised the doctrine to expand the class of moot cases that federal courts may hear. Courts are, in short, applying something other than the doctrine they claim to apply. ${ }^{170}$ Part III further analyzes the cases in order to begin to derive the "real" doctrine of mootness-the doctrine that courts actually apply.

course, ample reason to doubt that plaintiff would vigorously advocate the issues, in light of his sworn statement that he had no ongoing interest in the subject matter.

167 Id. at 287-88 (majority opinion) (stating that Pap's "could again decide to operate a nude dancing establishment in Erie," and hinting at concerns about Pap's veracity).

168 The Court held that the simple possibility that it might reverse the state court injunction prohibiting Erie from enforcing the public nudity provisions of its ordinance and thereby affecting the defendant's rights was "sufficient to prevent the case from being moot." Id. at 288 .

169 See id. at 302 (Scalia, J., concurring in part and concurring in the judgment); $c f$. S. Spring Hill Gold Mining Co. v. Amador Medean Gold Mining Co., 145 U.S. 300, 301 (1892) (on appeal of action between two corporations that came under control of same person after judgment was rendered in lower court, "litigation has ceased to be between adverse parties, and the case therefore falls within the rule applied where the controversy is not a real one"); Waite v. Dowley, 94 U.S. 527, 534 (1877) ("This court does not sit here to try moot cases to solve a question which may never be raised by any party entitled to raise it.").

170 See Daniel J. Meltzer, Deterring Constitutional Violations by Law Enforcement Officials: Plaintiffs and Defendants as Private Attorneys General, 88 Colum. L. Rev. 247, 302-03 (1988) (stating that in cases applying capable of repetition or class action exceptions, "[i]t seems fair to say that . . . the litigant is permitted to advocate the rights of third parties . . in order to assure ... adequate deterrence of the misconduct involved"). 


\section{Toward a Coherent Doctrine of Mootness}

If the constitutional model is both descriptively inaccurate and internally inconsistent, two questions naturally arise: How do courts decide mootness questions, and how should they decide them? Are judicial decisions in the mootness area arbitrary and unprincipled, as some scholars have suggested, ${ }^{171}$ or is there an intelligible doctrine hidden amidst the clutter that can help explain the results in past cases, and guide courts to the best results in the widest range of future cases?

I argue that judicial practice can be reconciled with theory by recognizing that there are two distinct kinds of mootness, which meritand, in the pertinent subset of cases, frequently already receive-substantially different judicial treatment. Cases may become moot either because post-filing events moot the issue raised in the claim, or because those events moot plaintiff's personal stake in that issue. The former type of mootness (which I refer to as "issue mootness") raises concerns of a different sort than the latter type of mootness ("personal stake mootness"). Federal courts confronting mootness issues appear to apply a two-part doctrine of mootness that requires dismissal of "issue moot" cases, but gives courts discretion to hear "personal stake moot" cases, or not, as they deem appropriate.

In applying this two-part doctrine of mootness, courts begin with the question of whether the harm alleged is reasonably likely to recur as to anyone-which implicates the question of whether any order the court might issue would affect the status quo. This is the question of "issue mootness," and a finding that the issue is moot means that the case no longer presents a case or controversy and thus must be dismissed. If the court finds the issue raised by plaintiff's claim is not itself moot, the next question is whether the plaintiff's personal stake in that issue is moot. If so, then the claim is subject to dismissal at the court's discretion.

Part III.A introduces this distinction and shows that this two-part model of mootness is more consistent with mootness case law than the

171 See, e.g., Chemerinsky, supra note 13, at 692 ("The only apparent answer sounds terribly cynical: a requirement is constitutional if the Court says it is, and it is prudential if the Court says it is that."); see also Lee, supra note 11, at 631 (stating that the Court "has sometimes obscured its reasoning about the personal stake requirement" when applying mootness doctrine); Pushaw, supra note 11, at 490 (noting that exceptions to mootness doctrine "are incomprehensible if federal courts lack Article III jurisdiction to resolve moot cases at all"); Shults, supra note 11, at 1035 ("[E]xceptions to the personal stake requirement are difficult to understand if mootness is constitutionally required and suggest that the doctrine has been applied more as a matter of discretion."). 
constitutional model, illustrating the point with several well known, and widely misunderstood, mootness cases. Part III.B addresses the factors that should - and, often already do-guide courts' exercise of discretion in determining whether or not to hear a case that is moot only in the personal stake sense. Part III.C defends this partially prudential model of mootness by analogy to the doctrine of third-party standing, under which courts have long permitted plaintiffs with standing to raise the claims of certain absent third parties. Part III.D argues that this partially prudential model of mootness is both better justified than prior proposals to treat mootness as entirely prudential, and more capable of ready adoption, because it can be adopted by lower courts based on the existing stock of precedent.

\section{A. The Two Doctrines of Mootness: Issue Mootness and Personal Stake Mootness}

The term "moot" in contemporary legal discourse refers to at least two distinct concepts: the expiration of the substantive issue involved in a claim, and the expiration of the plaintiff's personal stake in that issue. ${ }^{172}$ Despite the prevalence of constitutional rhetoric in modern mootness case law, the Supreme Court has actually treated "moot" cases very differently depending on whether they were moot in the sense of "issue mootness" or in the sense of "personal stake mootness." While courts invariably dismiss "issue moot" cases, ${ }^{173}$ a long line of cases suggests that the mootness doctrine is far more flexible with regard to personal stake mootness. Indeed, in many cases, courts have effectively treated dismissal on mootness grounds as nonmandatory in circumstances where only the plaintiff's personal stake is moot. ${ }^{174}$

172 Murphy v. Hunt, 455 U.S. 478, 481 (1982) (per curiam) (holding that a case becomes moot when "the issues presented are no longer 'live' or the parties lack a legally cognizable interest in the outcome"); U.S. Parole Comm'n v. Geraghty, 445 U.S. 388, 396 (1980) ("It is clear that the controversy over the validity of the Parole Release Guidelines is still a 'live' one between petitioners and at least some members of the class respondent seeks to represent .... We therefore are concerned here with the second aspect of mootness, that is, the parties' interest in the litigation. The Court has referred to this concept as the 'personal stake' requirement.").

173 See, e.g., United States v. Chambers, 291 U.S. 217, 224 (1934) (prosecution for violation of the National Prohibition Act dismissed as moot because statute was rendered inoperative by the Twenty-First Amendment's repeal of the Eighteenth Amendment without a saving clause); United States v. Alaska S.S. Co., 253 U.S. 113, 115-16 (1920) (civil action for injunction against agency order requiring shippers to use particular bill of lading form dismissed as moot where intervening statute required changes in forms).

174 Geraghty, 445 U.S. at 400-01; Sosna v. lowa, 419 U.S. 393, 401-02 (1975); Dunn v. Blumstein, 405 U.S. 330,333 n.2 (1972). 
The seeds of a distinction between personal stake mootness and issue mootness can be traced to the Supreme Court's 1980 decision in United States Parole Commission v. Geraghty. ${ }^{175}$ In that case, the Court seemed to suggest that mootness doctrine had two aspectswhether the issue was "live" as to anyone and whether the plaintiff had retained an ongoing interest in it. ${ }^{176}$ But although the Court held that the mootness bar is more flexible where only plaintiff's personal stake was moot, it also recited that mootness remains a jurisdictional doctrine, and it never clarified the boundaries of the constitutional concern. ${ }^{177}$ Subsequent cases following Geraghty have perpetuated this uncertainty, continuing to treat personal stake mootness inconsistently. ${ }^{178}$

The plaintiff in Geraghty sought to represent a class to challenge the Parole Commission's Release Guidelines on statutory and constitutional grounds. ${ }^{179}$ While his appeal from the denial of class certification was pending, the plaintiff was released from prison, which of course rendered his personal stake in the relief sought-an injunction requiring changes in the Release Guidelines-moot. ${ }^{180}$ Although his personal stake had expired, the issue that he sought to litigate remained live. The Third Circuit declined to dismiss the plaintiff's appeal as moot, and the Supreme Court affirmed. ${ }^{181}$

The Court began its analysis by distinguishing two kinds of "moot" cases: those in which the issues presented are no longer "live," and those in which the plaintiff no longer has a legally cognizable interest in the outcome. ${ }^{182}$ The Court held that the two categories of cases could properly be treated differently under Article III-the former sort of moot case should simply be dismissed, ${ }^{183}$ while mootness

175 U.S. Parole Comm'n v. Geraghty, 445 U.S. 388 (1980).

176 See id. at 396.

177 See id. at 396-97.

178 See, e.g., City of Erie v. Pap's A.M., 529 U.S. 277, 287-89 (2000) (reciting that justiciability is a threshold question of jurisdiction, but declining to dismiss based on "[o]ur interest in preventing litigants from attempting to manipulate the Court's jurisdiction to insulate a favorable decision from review"); see ülso Meltzer, supro note 170. at 302 (describing as "strained" the Court's efforts to find "that the named plaintiff maintained a personal stake" in various cases under the class action exception).

179 Geraghty, 445 U.S. at 390, 393.

180 Id. at 393-94; cf. Weinstein v. Bradford, 423 U.S. 147, 149 (1975) (per curiam) (dismissing as moot plaintiff's challenge to parole board procedures where his custody had ended).

181 See Geraghty, 445 U.S. at 404-07.

182 See id. at 396.

183 See id. at 396. The Court held that this was not such a case, because "[i]t is clear that the controversy over the validity of the Parole Release Guidelines is still a live one between petitioners and at least some members of the class respondents seek to represent." Id. 
doctrine is more "flexible" in cases that were rendered moot only by the plaintiff's loss of a personal stake in the outcome. ${ }^{184}$ The Court stated that prior decisions demonstrate the prudential basis of the mootness exceptions: "[T]he strict, formalistic view of Art. III jurisprudence, while perhaps the starting point of all inquiry, is riddled with exceptions. And, in creating each exception, the Court has looked to practicalities and prudential considerations." 185

The Court then explained what sorts of "practicalities and prudential considerations" ought to guide courts in deciding whether to dismiss as moot cases where the issue remained live but plaintiff's personal stake had become moot. Rather than applying a "rigidly formalistic approach to Art. III," ${ }_{186}$ Geraghty held that courts should be guided by the purpose of the "personal stake" requirement, which is merely to ensure that the case is in a form capable of judicial review. ${ }^{187}$ "The imperatives of a dispute capable of judicial resolution" include (1) "sharply presented issues in a concrete factual setting," and (2) "self-interested parties vigorously advocating opposing positions." 188 These two requirements may be satisfied even where the named plaintiff's substantive claim has become moot because (1) the named plaintiff's loss of a personal stake does not render the issues any less concrete or sharply presented, ${ }^{189}$ and (2) vigorous advocacy can be assured through means other than the traditional requirement of a "personal stake in the outcome." 190

184 See id. at 399-400; see also id. at 401 (noting that cases in which the Court refused to dismiss based on plaintiff's loss of personal stake reveal that "Art. III justiciability is not a legal concept with a fixed content or susceptible of scientific verification"). The Court cited Gerstein v. Pugh, 420 U.S. 103 (1975), Deposit Guaranty National Bank v. Roper, 445 U.S. 326 (1980), and United Airlines, Inc. v. McDonald, 432 U.S. 385 (1977), as examples of cases found not to be moot despite the class representative's loss of a personal stake in the merits of the litigation. Geraghty, 445 U.S. at 399-400.

185 Id. at 406 n.11 (emphasis added); see also, e.g., Flint v. Dennison, 488 F.3d 816, 823 (9th Cir. 2007) ("Mootness . . is a flexible justiciability doctrine . . .."); United States v. Int'l Bhd. of Teamsters, 955 F.2d 171, 174 (2d Cir. 1992) ("[M]ootness doctrine is flexible and recognizes the uncertain and shifting contours for Article III justiciability."); S. Ohio Coal Co. v. Donovan, 774 F.2d 693, 698 (6th Cir. 1985) ("[M]ootness doctrine is a flexible concept with uncertain and shifting contours.").

186 Geraghty, 445 U.S. at 404 n.11.

187 Id. at 403.

188 Id.; see also Richard H. Fallon, Jr., Of Justiciability, Remedies, and Public Law Litigation: Notes on the Jurisprudence of Lyons, 59 N.Y.U. L. REv. 1, 51 (1984) (The "functional requisites of effective adjudication" are "[c]oncrete facts and adversarial presentation.").

189 See Geraghty, 445 U.S. at 403.

190 See id. at 404. 
The decision in Geraghty aroused a vigorous dissent by Justice Powell, joined by three other Justices. Justice Powell defended the orthodox constitutional model, insisting that the requirement of a live "personal stake" was "embedded in the case-or-controversy limitation imposed by the Constitution,"191 and rejected what he saw as the majority's holding "that the personal stake requirement lacks constitutional significance."192 Justice Powell acknowledged that, in the context of standing, "the personal stake requirement has a double aspect"193 because "[o]n the one hand [the requirement of personal stake] derives from Art. III limitations on the power of the federal courts. On the other, it embodies additional, self-imposed restraints on the exercise of judicial power." 194 But he insisted that mootness is different, and that the personal stake requirement in the mootness context is entirely mandatory. ${ }^{195}$

Geraghty's contribution to the proper understanding of mootness has been underappreciated. The Court specifically rejected dissenting Justice Powell's insistence that Article III required dismissal whenever plaintiff's personal stake evaporated prior to judgment. ${ }^{196}$ The Court described personal stake, rather, as merely one means to an end-the end being assurance that the case is "in a form capable of judicial resolution," which entails "sharply presented issues in a concrete factual setting and self-interested parties vigorously advocating opposing positions."197 If, as Geraghty held, the so-called "requirement" of a personal stake is but one means of serving the policies that underlie Article III, then a dismissal of a "personal stake moot" case is a discretionary decision, guided by "practicalities and prudential consider-

191 Id. at 412 (Powell, J., dissenting). Justice Powell also acknowledged that the case was moot, if at all, only in the sense that I term "personal stake moot." See id. at 409-10 ("There is undoubtedly a 'live' issue which an appropriate plaintiff could present for judicial resolution. The question is whether respondent, who has no further interest in this action, nevertheless may-through counsel-continue to litigate it.").

192 See id. at 410 n.1.

193 Id. at 410.

194 Id. (emphasis added).

195 Compare id. at 410 (stating that in the standing context, the requirement of personal stake "[includes both] Art. III limitations on the power of the federal courts [and] additional self imposed restraints"), with id. at 414 ("The Court announces today for the first time-and without attempting to reconcile the many cases to the contrary-that there are two categories of 'the Art. III mootness doctrine': 'flexible' and 'less flexible.'").

196 Compare id. at 414 (insisting that personal stake requirement is mandated by Article III) with id. at 404 (majority opinion) ("[V]igorous advocacy can be assured through means other than the traditional requirement of a 'personal stake in the outcome."”).

197 Id. at 403; see also id. at 403-04. 
ations," 198 including whether, in the circumstances of the case, the policies underlying Article III's Case or Controversy Clause are being served in some other way.

And Geraghty is just one of many Supreme Court cases that arguably follow-or at least are consistent with-this two-part, partially prudential model of mootness. Many cases that recite the rhetoric of the constitutional model nonetheless follow Geraghty in both recognizing (explicitly or implicitly) the two types of mootness and applying personal stake mootness as though it permits, but does not require, dismissal. Two illustrative examples are Dunn v. Blumstein and Rosario v. Rockefeller. ${ }^{199}$

In Dunn, the Tennessee voting registration case, the Court permitted a plaintiff with a moot personal stake to proceed based on the importance of the issue to the general public. ${ }^{200}$ In Rosario, the Court considered a challenge to a New York law requiring voters wishing to vote in a party primary to enroll as members of their party at least thirty days prior to the general election preceding the primary in which they intended to vote. ${ }^{201}$ At the time of decision, the Court noted, the relevant primary election "ha[d] been completed and the petitioners [would] be eligible to vote in the next scheduled New York primary."202 Again, this rendered the petitioners' claims moot in the personal stake sense, and any recurrence as to them would have required a speculative and unlikely chain of events. ${ }^{203}$ But although there was no reasonable likelihood of recurrence as to the petitioners, the Court found the claim to be nonmoot, "since the question the petitioners raise is "capable of repetition, yet evading review." "204 Thus, the fact that the question raised by the petitioners was reasonably likely to recur as to other members of the general public was itself sufficient to reject the assertion of mootness. ${ }^{205}$

198 Id. at 406 n.11.

199 Rosario v. Rockefeller, 410 U.S. 752 (1973).

200 See Dunn v. Blumstein, 405 U.S. 330, 333 n.2 (1972); see also supra Part II.B.2.

201 See Rosario, 410 U.S. at 753-56.

202 Id. at 756 n.5.

203 Specifically, it would require the petitioners to disenroll as members of their party, then later re-enroll in a political party at a time less than thirty days prior to the next scheduled primary election. The Court has held in other cases that such a series of events was too speculative to provide a reasonable likelihood of recurrence. See Hall v. Beals, 396 U.S. 45, 49-50 (1969) (per curiam) ("[S]uch speculative contingencies afford no basis for our passing on the substantive issues the appellants would have us decide ....").

204 Rosario, 410 U.S. at 756 n.5 (citation omitted).

205 Id.; see also Storer v. Brown, 415 U.S. 724, 737 n.8 (1974) (noting that "[t]he 1972 election is long over, and no effective relief can be provided to the candidates or voters, but this case 
Similarly, in Honig v. Doe-the case in which Chief Justice Rehnquist first questioned the constitutional model-the Supreme Court once again treated personal stake mootness very differently from issue mootness. Honig involved claims by two plaintiffs-referred to as Doe and Smith - that the defendant and petitioner had deprived them of rights under the Education of the Handicapped Act (the "Act").206 At the time the Supreme Court delivered its opinion, both plaintiffs' claims were arguably moot in the personal stake sense: Doe was twenty-four years of age, and thus no longer protected by the Act at all, ${ }^{207}$ while Smith was twenty, had moved out of the school district where the claimed violation of his rights occurred, and was no longer even enrolled in any public school. ${ }^{208}$ The Court emphasized that the issue raised by plaintiffs-whether disabled students could be suspended or expelled based on behavior caused by their disability-was very much alive, and focused its inquiry on Smith's personal stake in the outcome. ${ }^{209}$ Under the constitutional model, of course, each plaintiff's personal stake in the relief sought-an injunction forbidding their school district from expelling them-had expired: neither student was still enrolled in the district (or in any other public school district, for that matter). The constitutional model would therefore require dismissal of both plaintiffs' claims. ${ }^{210}$ A prudential model of mootness, on the other hand, would permit the Court to consider

is not moot, since the issues properly presented, and their effects on independent candidacies, will persist as the California statutes are applied in future elections. This is, therefore, a case where the controversy is capable of repetition, yet evading review."). In Storer, the Court expressly based its decision on practical considerations, noting that deciding the case would "have the effect of simplifying future challenges" and would thereby increase the likelihood that future cases raising the same issues could swiftly be adjudicated. $I d$.

206 Honig v. Doe, 484 U.S. 305, 308-09, 312-17 (1988) (citing Education of the Handicapped Act, Pub. L. No. 91-230, 84 Stat. 175 (1970) (codified as amended in scattered sections of 20 U.S.C. $\S \S 1400-1485(2006)))$.

207 Id. at 318.

208 Id. at 318 \& n.6. Indeed, Smith's counsel had not indicated that her client would ever scck to reenter the nublic school system. Id.

209 See id. at 318-20.

210 See id. at 333 (Scalia, J., dissenting) (interpreting constitutional model of mootness to require dismissal of both plaintiffs' claims); see also, e.g., U.S. Parole Comm'n v. Geraghty, 445 U.S. 388, 410-11 (1980) (Powell, J., dissenting) (arguing that Article III requires that plaintiff maintain an ongoing personal stake in the outcome of the litigation until adjudication is completed); Weinstein v. Bradford, 423 U.S. 147, 149 (1975) (per curiam) (expired personal stake mandates dismissal of action). Indeed, Chief Justice Rehnquist concurred in the Court's opinion in Honig holding the claims nonmoot, and wrote separately precisely to explain that the decision of the Court in Honig-as well as decisions in many other mootness cases-could not be squared with the constitutional model. See Honig, 484 U.S. at 329-30 (Rehnquist, C.J., concurring). 
other factors and exercise discretion whether to dismiss plaintiffs' claims-precisely as the Honig court actually did. ${ }^{211}$

What these cases-and the many others in which the federal appellate courts and Supreme Court have declined to dismiss claims as moot even though there was no demonstrated likelihood of recurrence as to the named plaintiff-reveal is that where the named plaintiff's stake in the claim for prospective relief has been rendered moot, federal courts do not treat plaintiff's ongoing personal stake as a prerequisite to jurisdiction. Instead, they often exercise jurisdiction even absent a showing of likely recurrence as to the named plaintiff. ${ }^{212}$ Personal stake is, in effect, treated as but one of many ways to satisfy certain policy goals-and it is those policy goals themselves, and not the requirement of a live personal stake - that are considered to be derived from Article III. In addition to the disability and election law cases cited above, this pattern is apparent in substantive areas including abortion, ${ }^{213}$ the Establishment Clause, ${ }^{214}$ and miscellaneous other cases. $^{215}$

Even Justice Scalia-the most ardent defender of the constitutional model in the forty-five years since Liner-has conceded the descriptive point, noting that the Supreme Court has previously "dispens[ed] with the same-party requirement entirely" in election

211 See Honig, 484 U.S. at 317-23 (majority opinion). The Court dismissed only Doe's claim, holding that Smith's claim was not moot on account of his continued eligibility for benefits under the Act. Id.

212 See, e.g., Geraghty, 445 U.S. at 388; Storer v. Brown, 415 U.S. 724, 737 n.8 (1974); Dunn v. Blumstein, 405 U.S. 330,333 n.2 (1972).

213 See, e.g., Roe v. Wade, 410 U.S. 113, 125 (1973) (holding that "[p]regnancy provides a classic justification for a conclusion of nonmootness" because the duration of an individual pregnancy is so short as to effectively deny appellate review when pregnancy is a significant fact in the litigation, but "[p]regnancy often comes more than once to the same woman, and in the general population, if man is to survive, it will always be with us"); see also Bellotti v. Baird, 428 U.S. 132, 137 n.7 (1976); Doe v. Bolton, 410 U.S. 179, 187 (1973).

214 See, e.g., Grossberg v. Deusebio, 380 F. Supp. 285, 292 (E.D. Va. 1974). In Grossberg, the court held that a claim by high school students and their parents seeking injunction against a religious component of a graduation ceremony was not rendered moot by the students' graduation, even though plaintiffs "will never again be susceptible to the conduct of which they complained." Id. Hearing plaintiffs' claim was appropriate, the court explained, because it "[was] the only effective means to insure full and deliberate adjudication of the Establishment [Clause] issues they raise." Id.

215 See, e.g., Deposit Guar. Nat'l Bank v. Roper, 445 U.S. 326, 332-33 (1980) (alleged violation of state usury law); Gerstein v. Pugh, 420 U.S. 103, 111 n.11 (1975) (alleged Fourth Amendment violations); Sosna v. Iowa, 419 U.S. 393, 397-403 (1975) (constitutional challenge to durational residency requirement for divorce); Am. Healthcare Corp. v. Schweiker, 688 F.2d 1072, 1076-77 n.10 (7th Cir. 1982) (challenge to termination of medical provider status with Medicare); Trachtman v. Anker, 563 F.2d 512, 514 n.1 (2d Cir. 1977) (First Amendment). 
and abortion law cases, and focused instead on the "great likelihood that the issue will recur between the defendant and the other members of the public at large without ever reaching us."216 In an opinion that was joined by no other member of the Court, however, Justice Scalia attempted artificially to limit the effect of this line of authority, stating that:

Arguably those cases have been limited to their facts, or to the narrow areas of abortion and election rights, by our more recent insistence that, at least in the absence of a class action, the "capable of repetition" doctrine applies only where there is a reasonable expectation that the same complaining party would be subjected to the same action again. ${ }^{217}$

There are two flaws in Justice Scalia's attempt to harmonize these cases with the constitutional model of mootness. First, as noted above, Scalia's factual premise is unquestionably mistaken: the courts have frequently applied the "capable of repetition, yet evading review" exception in cases with no likelihood of recurrence as to the same plaintiff, where the substantive claims concerned neither election nor abortion law, ${ }^{218}$ and in cases not pled as class actions. ${ }^{219}$

Second, and more fundamental, Justice Scalia's concession is fatal to the constitutional model of mootness, even if the case law supported his proposed limitation of scope. Even if the Court's tendency to disregard the same-plaintiff "requirement" (and expand the capable-of-repetition exception as needed to enable it to hear important cases) were limited to class actions or to the narrow substantive areas suggested by Justice Scalia, it would still demonstrate that the Court was not applying mootness as a true jurisdictional limitation. There is,

216 Honig, 484 U.S. at 335-36 (Scalia, J., dissenting) (emphasis omitted).

217 Id. at 336 (Scalia, J., dissenting) (quotations omitted).

218 Honig itself, of course, is one such case. Id. at 317-23 (majority opinion) (applying capable of repetition, yet evading review doctrine in holding student's claim under Act not moot even though the student (1) no longer resided within school district where violation was alleged to have occurred, (2) was no longer attending public school, and (3) did not profess any interest in returning to public school); see aiso supra nơte 215 (citing sases from other areas of law).

219 See, e.g., Honig, 484 U.S. at 323; Rosario v. Rockefeller, 410 U.S. 752, 755-56 \& n.5 (1973) (finding consolidated cases challenging voter registration requirement nonmoot, where one case was brought as class action and the other was not, without according any significance to class action status); Dunn v. Blumstein, 405 U.S. 330, 333 n.2 (1972) (finding individual's claim nonmoot based on likely repetition of allegedly wrongful conduct as to others); Schaefer $v$. Townsend, 215 F.3d 1031, 1033 (9th Cir. 2000); Corrigan v. City of Newaygo, 55 F.3d 1211, 1214 (6th Cir. 1995); Trachtman, 563 F.2d at 514 \& n.1 ("Although the complaint did not formally so assert, Trachtman was litigating in a representational capacity. Plaintiffs seek to vindicate not only Trachtman's rights as an individual student, but the right of the [student newspaper] and its staff to conduct the survey.") (citations omitted); Grossberg, 380 F. Supp. at 292. 
after all, nothing in the Case or Controversy Clause that broadens federal jurisdiction with regard to election law and abortion, or to class actions. If a moot case is outside of Article III's grant of federal jurisdiction because it is not a "case or controversy," then that must be true even if the action concerns election law or abortion, and regardless of whether it satisfies Rule 23's requirements for a class action. ${ }^{220}$ Conversely, if the Court's exercise of jurisdiction over a subset of moot cases is proper-which Justice Scalia does not question-then the Court must have discretion to exercise jurisdiction over at least some moot cases in other substantive contexts.

In summary, the apparent incoherence in mootness case law is largely the product of the imprecise usage of the term "moot" to refer to two distinct sets of circumstances that appear to be governed by two distinct sets of rules. Once we recognize that there are two categories of mootness, and that they are governed by very different rules, the confusion resolves, and it becomes clear that there are two doctrines of mootness-one largely constitutional in nature, according to which a case raising only a moot issue must be dismissed, and the other largely prudential, pursuant to which federal courts may hear cases rendered moot by the expiration of plaintiff's personal stake, but, depending on the court's assessment of certain prudential factors, may also dismiss such cases. That the familiar "exceptions" to mootness apply only in cases of personal stake mootness ${ }^{221}$ reinforces the salience of this distinction.

Despite the continuing prevalence of constitutional rhetoric, the decisions of the Supreme Court reveal that it has repeatedly treated personal stake mootness as a discretionary doctrine, under which courts can dismiss or not as they deem appropriate in view of certain prudential considerations-the content of which will be discussed in Part III.B. The Court has applied this doctrine of personal stake mootness in class actions and individual actions, and in a variety of substantive areas of law. Recognition that this is what courts have been doing in the mootness area helps to resolve the apparent inconsistencies within mootness doctrine, and between the ostensible doc-

220 Cf. Verlinden B.V. v. Cent. Bank of Nig., 461 U.S. 480, 491 (1983) ("This Court's cases firmly establish that Congress may not expand the jurisdiction of the federal courts beyond the bounds established by the Constitution."); see also 13A WRIGHT ET AL., supra note 2, § 3521 .

221 The three major exceptions discussed supra are solely applicable in cases of personal stake mootness, as each of them applies only where recurrence is at least reasonably likely, while an issue moot case is, by definition, one that has no reasonable likelihood of recurrence as to anyone. See infra Part III.D. 
trine and the conflicting practice of courts in certain categories of mootness cases.

\section{B. The Factors That Guide Prudential Mootness Decisions}

My argument that Article III's Case or Controversy Clause does not mandate dismissal of all moot cases does not, of course, entail that Article III concerns have no role in mootness analysis. It is a fact that federal courts are generally reluctant to decide moot cases; however, the determination whether or not to decide a particular moot claim is made, not categorically (based on the answer to the single question "is it moot?"), but case by case, based on a variety of prudential factors, only some of which bear any evident relationship to Article III. These factors include at least the following: (1) whether the policies that are typically said to be served by justiciability doctrines are sufficiently satisfied under the circumstances of the case; (2) the importance of adjudicating the issue or issues promptly; (3) the effect on judicial authority of hearing and deciding the claim; and (4) the effect on the efficient use of judicial resources of hearing and deciding the claim.

\section{Whether Justiciability Policies Are Served by Hearing the Case}

The prudential vision of personal stake mootness that I have presented here regards plaintiff's personal stake not as a constitutional requirement in itself, but as a proxy for the policies that have been said to underlie justiciability doctrines. These justiciability policies are features - such as vigorous advocacy and the sharp presentation of legal issues in a concrete factual setting 222 - that courts consider desirable because they promote better judicial decisionmaking, and which might also be regarded as bearing some relation to Article III's Case or Controversy Clause. ${ }^{223}$ Thus, although I argue that personal stake is not-and has not generally been treated by federal courts as-a prerequisite for the exercise of federal jurisdiction, I

222 See, e.g., U.S. Parole Comm'n v. Geraghty, 445 U.j. $38 \overline{8}, 400 \overline{3}-04$ (1900) (ūvting that Sosna implicitly held that "vigorous advocacy" could be provided through means other than requiring personal stake); Sosna v. Iowa, 419 U.S. 393, 401-03 (1975) (implicitly holding that the policies embodied in Article III's Case or Controversy Clause, including the desirability of vigorous advocacy, may be satisfied through means other than requiring that plaintiff maintain a personal stake until the termination of the litigation).

223 See, e.g., Honig v. Doe, 484 U.S. 305, 331 (1988) (Rehnquist, C.J., concurring) (stating that "while an unwillingness to decide moot cases may be connected to the case or controversy requirement of Art. III, it is an attenuated connection that may be overridden where there are strong reasons to override it"). 
do concede that Article III and the policies underlying it play a role even in personal stake mootness analysis.

The first step in a proper, prudential, analysis of a personal stake mootness problem is to consider whether the circumstances of the present case are such that these justiciability policies adequately would be served by adjudicating the issue in the present case. In Geraghty, for example, far from insisting that personal stake was required by the Case or Controversy Clause, the Court emphasized the functions served by the personal stake requirement-namely, ensuring vigorous advocacy and concrete presentation of issues-and then expressly held that both interests could be served without requiring that plaintiff maintain an ongoing personal stake. ${ }^{224}$ That courts are following this prudential model of personal stake mootness, rather than the constitutional model, can be seen from the fact that they do not justify their exercise of jurisdiction by offering an interpretation of Article III's Case or Controversy Clause that would explain their exercise of jurisdiction over this moot case but not another. Rather, they discuss the factual circumstances in the particular case that support the conclusion that the justiciability policies will be served ${ }^{225}-$ that is, that in the present case the issues are sharply presented in a concrete factual setting, and that they will be vigorously advocated. ${ }^{226}$

\section{Whether the Circumstances Render Prompt Adjudication Desirable or Necessary}

The next category of prudential considerations that courts consider in deciding whether to hear moot claims is whether the circumstances of the case are such as to render a prompt adjudication necessary or desirable. If a claim appears moot it might nonetheless appear desirable, from a prudential point of view, to hear and decide the claim in the present action when one or both of the following circumstances is present: (1) the claim raised affects absent third parties,

224 See Geraghty, 405 U.S. at $403-04$.

225 See, e.g., Franks v. Bowman Transp. Co., 424 U.S. 747, 755-56 (1976) (stating that mootness of a class action depends on whether a sufficiently adversary relationship persists between the parties).

226 See, e.g., Geraghty, 445 U.S. at 403; Gerstein v. Pugh, 420 U.S. 103, 111 n.11 (1975) ("[I]n this case the constant existence of a class of persons suffering the deprivation is certain. The attorney representing the named respondents is a public defender, and we can safely assume that he has other clients with a continuing live interest in the case."); Dunn v. Blumstein, 405 U.S. 330, 333 n.2 (1972) ("[T]he laws in question remain on the books, and Blumstein has standing to challenge them as a member of the class of people affected by the presently written statute."). 
or otherwise concerns an issue of significant social importance, and (2) the wrong of which plaintiff complains might "evade review" if it is not reviewed now. Early decision might be desirable in circumstances where the alleged wrongful conduct is causing ongoing harm to others (or is likely to cause harm in the future to the plaintiff or to third parties $)^{227}$ - especially if those third parties face obstacles to effective assertion of their rights. ${ }^{228}$

Supreme Court case law reveals the importance to mootness decisions of this "evading review" concern: The Court has identified a variety of distinct factual circumstances in which moot claims come within federal jurisdiction, such as: (1) a class action challenge to a short durational residency requirement, where the district court has already certified the class at the time that mootness occurs; ${ }^{229}$ (2) a class action challenge to pretrial detention, whether or not the district court has certified a class; ${ }^{230}$ (3) a Rule $23(\mathrm{~b})(3)^{231}$ class action seeking damages, where defendant has tendered the full amount of the named plaintiff's damages; ${ }^{232}$ and (4) an individual action seeking to enjoin agency action. ${ }^{233}$ The Court has never offered an interpretation of the Case or Controversy Clause that would explain why each of these disparate factual contexts presents a "case" or "controversy" while other moot claims do not. The only thing that these various factual contexts appear to have in common is that they present circumstances where the application of a rule requiring dismissal would appear to insulate from judicial review a whole category of similar claims, because the

227 See, e.g., Dunn, 405 U.S. at 333 n.2 (approving lower court's treatment of mootness and stating that "[a]lthough appellee now can vote, the problem to voters posed by the Tennessee residence requirements is capable of repetition, yet evading review") (quotation and citation omitted); Roe v. Wade, 410 U.S. 113, 125 (1973) (endorsing lower court's treatment of mootness and noting pregnancy's propensity to recur, and certainty of recurrence as to general public).

228 This would be the case, for instance, in a challenge to a durational residency requirement, or any other claim that is inherently short lived, as all plaintiffs would predictably find their claims moot before final adjudication.

229 Sosna v. Iowa, 419 U.S. 393, 401-02 (1975).

230 See Gerstein, 420 U.S. at $111 \mathrm{n} .11$ ("The length of pretrial custody cannot be ascertained at the outsct, and it may he ended at any time by release on recognizance, dismissal of the charges, or a guilty plea, as well as by acquittal or conviction after trial. It is by no mieanis certain that any given individual, named as plaintiff, would be in pretrial custody long enough for a district judge to certify the class.").

231 FED. R. Civ, P. 23(b)(3).

232 See Deposit Guar. Nat'l Bank v. Roper, 445 U.S. 326, 339 (1980) ("Requiring multiple plaintiffs to bring separate actions, which effectively could be 'picked off' by a defendant's tender of judgment before an affirmative ruling on class certification could be obtained, obviously would frustrate the objectives of class actions ....").

233 See, e.g., S. Pac. Terminal Co. v. Interstate Commerce Comm'n, 219 U.S. 498, 515 (1911). 
same circumstance that rendered the claim moot would similarly affect every later claim. ${ }^{234}$ One might view these cases as defining a "necessity" exception to any mootness bar-pursuant to which courts could ignore the mootness bar where its application would likely insulate a challenged course of conduct from judicial review. ${ }^{235}$

\section{The Effect on Judicial Authority of Hearing the Claim}

Mootness may arise because of the action of a party to the litigation, which creates the potential for intentional manipulation of the mootness rules by litigants seeking strategic or tactical advantage. Courts have thus been quite reluctant to apply mootness doctrine in a manner that would give parties the ability unilaterally to destroy federal jurisdiction in order to preserve, or avoid, a judicial ruling. ${ }^{236}$ The entire doctrine of voluntary cessation may be seen as one manifestation of this concern with preventing party use of mootness rules to manipulate federal jurisdiction. ${ }^{237}$ But numerous other mootness decisions outside of the voluntary cessation area are animated by these concerns as well. A common variant occurs when a repeat litigant, such as the government or a large corporate defendant, seeks to secure mootness, even at the expense of losing the present case, in order to avoid bad precedent. In Khouzam v. Ashcroft, for instance, the

234 Courts have repeatedly stated that it would be unacceptable and contrary to sound judicial administration to render a whole category of cases immune from judicial review, see, e.g., Corrigan v. City of Newaygo, 55 F.3d 1211, 1214 (6th Cir. 1995) (holding case nonmoot in part because "[t]o hold this case moot would require the absurd result that a court would never be able to rule on the Newaygo ordinance"). However persuasive this argument may be from a prudential standpoint, it would be irrelevant if mootness were actually being applied as a jurisdictional bar, given that the very purpose of a jurisdictional limitation is to define a category of cases that is not subject to judicial review.

235 See, e.g., id. For a slightly different characterization, see Suntharalinkam v. Keisler, 506 F.3d 822, 830 (9th Cir. 2007) (Kozinski, J., dissenting) (noting that litigation can be completed very swiftly, albeit at a high cost to both the judicial system and parties, and that the capable of repetition, yet evading review exception may best be seen as a rule of "judicial convenience" to permit courts to proceed at a slower pace).

236 See, e.g., City of Erie v. Pap's A.M., 529 U.S. 277, 288 (2000) ("Our interest in preventing litigants from attempting to manipulate the Court's jurisdiction to insulate a favorable decision from review further counsels against a finding of mootness here."); United States v. W.T. Grant Co., 345 U.S. 629, 632 \& n.5 (1953); see also Khouzam v. Ashcroft, 361 F.3d 161, 167-68 (2d Cir. 2004) (rejecting contention of mootness where litigant sought to avoid an unfavorable ruling).

237 See, e.g., Grant, 345 U.S. at 632 n.5 (describing voluntary cessation doctrine as “"the duty of the courts to beware of efforts to defeat injunctive relief by protestations of repentance and reform, especially when abandonment seems timed to anticipate suit, and there is probability of resumption" " (quoting United States v. Or. State Med. Soc'y, 343 U.S. 326, 333 (1952))). 
government agreed-after oral argument-to vacatur of a Board of Immigration Appeals deportation order, in an apparent effort to avoid a court ruling regarding the government's definition of torture. 238 The Court rejected the contention of mootness and proceeded to the merits, commenting that it was "troubled by the government's tactics here" in conceding defeat in the present case in order to avoid an adverse court ruling. ${ }^{239}$

These issues arise most frequently with respect to equitable relief claims, where defendants seek to procure mootness in order to avoid adjudication. But there are other, far less frequent, variants-for instance, (1) plaintiffs seeking to moot their own claims for strategic reasons, or (2) parties seeking to moot damages claims - that demonstrate that courts are ever-vigilant to prevent parties from gaming mootness to destroy federal jurisdiction.

First, because it is plaintiffs who initially seek relief from the courts, it is most often defendants who seek to procure mootness in order to avoid adjudication of a claim. But it is not always so. The Court has been equally vigilant to protect judicial authority in the rare circumstance where plaintiffs appear to be gaming the mootness doctrine by seeking to procure mootness for strategic reasons. In City of Erie v. Pap's A.M., for example, the Court refused to dismiss the case as moot on plaintiff's own motion, where plaintiff had gone out of business and sold the real estate on which the business had previously been operated. ${ }^{240}$ The lower court injunction was still in place, and the Court expressed the concern that plaintiff might have closed the business in an effort to establish mootness and thereby protect the injunction from Supreme Court review. ${ }^{241}$ Despite the fact that only the defendant still claimed to be interested in the subject matter of the litigation, the Court held that the case was not moot, based on this concern about possible gamesmanship. ${ }^{242}$

238 Khouzam v. Ashcroft, 361 F.3d 161, 168 (2d Cir. 2004) (characterizing issue of government's definition of torture as "dispositive in Khouzam's case, [as well as] clearly an issue of pubiic imporianice").

239 Id. at 168 ("[Torture] is clearly an issue of public importance. For the government to agree to a vacatur two weeks after oral argument suggests that it is trying to avoid having this Court rule on that issue.")

240 City of Erie v. Pap's A.M., 529 U.S. 277, 287-89 (2000). In Pap's A.M., the plaintiff, operator of a nude dancing establishment, challenged an anti-nudity ordinance. After securing an injunction below, plaintiff decided to retire, closed the business, and sold the real estate on which the business had operated. Id. at 284-85.

241 Id. at 288-89.

242 Id: see also Albers v. Eli Lilly \& Co., 354 F.3d 644, 646 (7th Cir. 2004) (refusing to dismiss claim on petitioner's motion, stating: "One good reason to exercise discretion against 
Second, although any discussion of mootness typically will be concerned primarily with injunctive or other equitable relief, (because damages claims rarely become moot), ${ }^{243}$ the issues presented by party efforts to game mootness for strategic advantage may occasionally arise with respect to damages claims as well. For example, a plaintiff's damages claim ordinarily may be mooted by a Rule 68 offer of judgment in the full amount of the plaintiff's claim. ${ }^{244}$ But where a plaintiff proceeds in a representative capacity, such as in a class action, a Rule 68 offer to the named plaintiff might be used in an effort to moot the claim prior to a court decision on class certification (and thus perhaps to avoid a decision on the merits entirely). ${ }^{245}$ In such cases, courts have not hesitated to protect their authority and prevent party manipulation by rejecting the contention of mootness. ${ }^{246}$

\section{The Effect on Judicial Efficiency of Hearing the Claim}

Courts are, of necessity, always concerned with efficiently using their limited judicial resources, ${ }^{247}$ and efficiency concerns often animate determinations on matters of justiciability. ${ }^{248}$ The Supreme

dismissal is to curtail strategic behavior .... We think it best ... to carry through ... [so that] an attempt to make the stock of precedent look more favorable than it really is may be foiled."); $c f$. Suntharalinkam v. Keisler, 506 F.3d 822, 828 (9th Cir. 2007) (Kozinski, J., dissenting) ("That petitioner's counsel has filed a motion that can do his client zero good, and possibly great harm, for no apparent reason other than to avoid an adverse ruling that would affect other parties in other cases, militates strongly against exercising our discretion in favor of granting the motion at this late date.").

243 Perhaps it is more accurate to say that in those circumstances when a damages claim does become moot, it is exceedingly rare to have a plaintiff who still wishes to litigate, because for a damages claim to become moot the defendant ordinarily must pay it in full-or bindingly agree to do so, as by an offer of judgment under Rule 68. See Fed. R. Civ. P. 68.

244 See, e.g., Weiss v. Regal Collections, 385 F.3d 337, 340 (3d Cir. 2004) (“An offer of complete relief will generally moot the plaintiff's claim, as at that point the plaintiff retains no personal interest in the outcome of the litigation."); see also FED. R. CIV. P. 68.

245 See Weiss, 385 F.3d at $340-42$.

246 See, e.g., Deposit Guar. Nat'l Bank v. Roper, 445 U.S. 326, 339 (1980) (rejecting contention of mootness based on practical concern that it would undermine Rule 23 and waste judicial resources, because "[r]equiring multiple plaintiffs to bring separate actions, which effectively could be 'picked off' by a defendant's tender of judgment before an affirmative ruling on class certification could be obtained, obviously would frustrate the objectives of class actions; moreover it would invite waste of judicial resources by stimulating successive suits brought by others claiming aggrievement"); see also Weiss, 385 F.3d at 344 (reversing mootness dismissal based on practical concern that "allowing the defendants here to 'pick off' a representative plaintiff with an offer of judgment less than two months after the complaint is filed may undercut the viability of the class action procedure, and frustrate the objectives of this procedural mechanism for aggregating small claims").

247 See, e.g., Arizonans for Official English v. Arizona, 520 U.S. 43, 75-76 (1997).

248 See, e.g., Roper, 445 U.S. at 339. 
Court has noted that dismissal on justiciability grounds at an early stage of the litigation may conserve judicial resources, whereas dismissal at a later stage of an action, when significant judicial resources have already been expended, may waste judicial resources, particularly when the claim is likely to recur. ${ }^{249}$ Thus, dismissals for mootness will, as a general rule, do less to conserve judicial resources than dismissals for lack of standing, and may actually waste resources. ${ }^{250}$ The Case or Controversy Clause, of course, says nothing about sunk costs. ${ }^{251}$ Thus, the constitutional model of mootness, which insists that any moot case must be dismissed because it does not present a case or controversy, does not permit courts to weigh the effect on judicial efficiency of a dismissal. The Supreme Court, however, has held that it is entirely proper for federal courts to give weight to "sunk costs" in ruling on mootness decisions. ${ }^{252}$

The contrast between the rhetoric and reality of mootness case law could hardly be more stark. Courts discuss mootness as though it were a unified, jurisdictional doctrine, but regularly determine whether to dismiss personal stake moot cases based on their assessment of a constellation of prudential factors, most of which bear no evident relation to the Case or Controversy Clause. ${ }^{253}$ The Courts' consideration of these pragmatic concerns is sensible from a prudential standpoint, but cannot be explained under the orthodox constitutional model of mootness. If the mootness analysis were truly as simple as the constitutional model professes-a moot case is simply not a "case" or a "controversy," and thus is beyond federal jurisdiction-then it would not matter, for instance, whether the alleged wrong also harms third parties who face obstacles to asserting their own rights, or whether dismissal would waste limited judicial resources, or even whether mootness was procured by a party seeking to

249 See Friends of the Earth v. Laidlaw Envtl. Servs., Inc., 528 U.S. 167, 191-92 (noting that standing doctrine functions to preserve scarce federal judicial resources by excluding cases early, whereas dismissal of a case as moot after years of litigation "may prove more wasteful than frugal").

250 See id.

251 See U.S. CONST. art. III, $\S 2$.

252 Friends of the Earth, 528 U.S. at 192 (noting that courts may consider sunk costs in mootness analysis, which "highlights an important difference between the [standing and mootness] doctrines").

253 See, e.g., Honig v. Doe, 484 U.S. 305, 330-31 (1988) (Rehnquist, C.J., concurring) (noting that Court's consideration of effect on third parties demonstrates that "while an unwillingness to decide moot cases may be connected to the case or controversy requirement of Art. III, it is an attenuated connection that may be overridden where there are strong reasons to override it"). 
manipulate federal jurisdiction. Although one can mount fairly compelling arguments from the standpoint of sound judicial administration for the results in all of these cases, those arguments are entirely prudential in nature, and are not based on any reading of the text or history of Article III's Case or Controversy Clause. That courts take account of these factors in deciding whether to dismiss personal stake moot cases reveals the prudential nature of personal stake mootness.

\section{The Doctrine of Third-Party Nonmootness}

As I have argued, the Court has tended to treat personal stake mootness-in class actions and in the subset of "capable of repetition, yet evading review" cases in which the likely recurrence is as to someone other than plaintiff-as favoring but not requiring dismissal. This treatment is consistent with the Court's treatment of personal stake in the context of other justiciability doctrines. Third-party standing doctrine has long permitted plaintiffs to establish the justiciability of their claims by asserting the rights of absent third parties. And, most critically, the Court has always regarded the decision whether or not to permit plaintiffs to rest their claim for relief on the rights of others as a discretionary decision for the court. ${ }^{254}$

But if the way courts handle personal stake mootness is consistent with the application of third-party standing, there remains, at least nominally, a crucial doctrinal difference. Like mootness, thirdparty standing takes the form of a general prohibition against a plaintiff's establishing the justiciability of her claim by reference to the rights of a third party. ${ }^{255}$ But in the standing context, the Court has always treated the general rule barring plaintiffs from asserting the rights of third parties as prudential in nature-that is, as a restriction imposed by the courts, and not a mandatory limitation imposed by Article III. ${ }^{256}$ Yet courts persist in labeling the rule favoring dismissal of personal stake moot claims as mandatory and jurisdictional.

254 The general rule about third party standing is that plaintiffs may not assert the rights of others. The important point for our purposes, however, is that that rule is regarded as purely prudential-meaning that courts have discretion to permit a party to rest his claim for relief on the rights of others. See Warth v. Seldin, 422 U.S. 490, 499, 500-01 (1975); see also United Food \& Commercial Workers Union Local 751 v. Brown Group, Inc., 517 U.S. 544, 557 (1996) (discussing prudential nature of the prohibition against third party standing).

255 See, e.g., Warth, 422 U.S. at 499 (stating the general prudential rule that "even when the plaintiff has alleged injury sufficient to meet the 'case or controversy' requirement, this Court has held that the plaintiff generally must assert his own legal rights and interests, and cannot rest his claim to relief on the legal rights or interests of third parties").

256 See, e.g., id. at 499-500; see also Allen v. Wright, 468 U.S. 737, 751 (1984) (referring to "the general prohibition on a litigant's raising another person's legal rights" as a self-imposed 
There is no persuasive justification for this doctrinal difference between standing and mootness. If, in the context of standing, Article III presents no bar to a plaintiff establishing a justiciable claim for relief by reference to the rights of others, then it is difficult to see why the analysis in the mootness context should differ. ${ }^{257}$ The same policy concerns apply in both contexts. The three major exceptions to the prudential bar against third-party standing each appear to serve prudential concerns similar to those articulated above in Parts III.B.1 and B.2. The three exceptions are: (1) where the third party faces obstacles to the assertion of her own rights;258 (2) where there is a close relationship between the plaintiff and the third party;259 and (3) where the wrong complained of may chill protected expression by third parties (the First Amendment overbreadth doctrine). ${ }^{260}$ The first and third exceptions are analogous to the mootness case law that permits courts to exercise jurisdiction if the wrong complained of by plaintiff harms third parties who face obstacles to the assertion of their own rights. ${ }^{261}$ The second serves the justiciability policy of promoting vigorous assertion of rights and the sharp presentation of issues in a concrete factual context. Taken together, these exceptions demonstrate

limitation on federal judicial power and not part of the "core component [of standing] derived directly from the Constitution"). It is well established that the Case or Controversy Clause presents no barrier to federal courts' exercise of discretion under third-party standing doctrine. As long as the case presents a case or controversy, the question of who is a proper party to assert the claim is regarded as a matter within the court's discretion. See id. at 500-01; see also United Food \& Commercial Workers, 517 U.S. at 557.

257 For a related criticism, see Chemerinsky, supra note 13, at 692 ("[W]hat makes some requirements constitutional and the others prudential? For example, why are injury, causation, and redressability deemed constitutionally mandated, but the rules against third party standing and generalized grievance merely prudential? ... The only apparent answer sounds terribly cynical: a requirement is constitutional if the Court says it is, and it is prudential if the Court says it is that.")

258 See, e.g., Eisenstadt v. Baird, 405 U.S. 438, $443-46$ (1972) (holding that plaintiff convicted of providing contraceptive could assert rights of persons wishing to use contraceptives where those persons lacked ability to assert their own rights); Griswold v. Connecticut, 381 U.S. 479,481 (1965) (holding that physician charged with criminal offense for providing contraceptives could challenge constitntionality of statute based on asserted privacy rights of customer).

259 See, e.g., Pierce v. Soc'y of Sisters, 268 U.S. 510, 535-36 (1925) (holdıng that parucinial school could assert rights of families to make educational choices for their children).

260 See, e.g, Vill. of Schaumberg v. Citizens for a Better Env't, 444 U.S. 620, 634 (1980) (permitting litigant whose own activities were unprotected to challenge a statute by showing that it substantially abridges the First Amendment rights of other parties not before the court).

261 See, e.g., Dunn v. Blumstein, 405 U.S. 330, 333 n.2 (1972); Hall v. Beals, 396 U.S. 45, 50-51 (1969) (Brennan, J., dissenting) (noting that rules of ripeness may prevent a potential future plaintiff from challenging the law prior to its application to him); cf. Roe v. Wade, 410 U.S. 113, 128-29 (1973) (finding nonjusticiable the claims of a plaintiff who was not yet pregnant but feared application of abortion restriction to her in event of future pregnancy). 
the Court's recognition, at least in certain contexts, that each of these factors is but one of many prudential considerations to guide courts in determining whether to exercise jurisdiction.

Thus, the established rule that the bar on third-party standing is only prudential provides support by analogy for the notion that the personal stake mootness of a claim asserted by a plaintiff with initial standing presents no obstacle to the exercise of jurisdiction by a federal court. The courts' flexible treatment of personal stake mootness-whether in class actions or otherwise-can be understood as representing a purely prudential doctrine of third-party nonmootness. Given their familiarity with third-party standing doctrine, it is perhaps not surprising that, as discussed above in Part III.B, federal courts have tended to treat mootness in precisely the same way, holding that once the plaintiff has established initial standing, later events that destroy her personal stake may weigh against the exercise of jurisdiction, but they do not bar it per se. ${ }^{262}$

In view of the overlapping policy concerns and the courts' far more theoretically defensible treatment of third-party standing, it becomes ever more difficult to understand the persistence of the constitutional model of mootness.

\section{Why Not Deconstitutionalize Issue Mootness As Well?}

The constitutional model of mootness has been criticized as incomprehensible ${ }^{263}$ and unnecessary, ${ }^{264}$ and some have argued for its wholesale abandonment. ${ }^{265}$ This Article has proposed recognizing the prudential nature of personal stake mootness, while retaining a constitutional conception of issue mootness. One objection that might be

262 See, e.g., U.S. Parole Comm'n v. Geraghty, 445 U.S. 388, $400-07$ (1980); Rosario v. Rockefeller, 410 U.S. 752,756 n.5 (1973); Roe, 410 U.S. at 125; Dunn, 405 U.S. at 333 n.2; Grossberg v. Deusebio, 380 F. Supp. 285, 292 (E.D. Va. 1974).

263 See Pushaw, supra note 11, at 490 (mootness exceptions are "incomprehensible" if federal courts lack Article III jurisdiction to resolve moot cases); see also Shults, supra note 11, at 1035 ("[E]xceptions to the personal stake requirement are difficult to understand if mootness is constitutionally required .....").

264 See, e.g., 13A WRIGHT ET AL., supra note 2, §3533.1 ("There is reason to wonder whether much reliance should be placed on Constitutional concepts of mootness when these concepts are as flexible as they are and all ordinary needs can be met by the discretionary doctrines.").

265 See Lee, supra note 11, at 605 (arguing that mootness should be "transform[ed]" into a wholly prudential doctrine). For arguments that mootness has always been entirely prudential, see Shults, supra note 11, at 1036 (arguing that "the [mootness] doctrine has been applied more as a matter of discretion"), and Pushaw, supra note 11, at 490 (arguing that "mootness is, and always has been, a matter of discretion"). 
raised is that the proposal does not go far enough-that issue mootness, as well, should be regarded as a prudential doctrine not required by Article III's Case or Controversy Clause. There are, however, three principal reasons for stopping short of deconstitutionalizing mootness in its entirety.

First, the case has not yet been made for deconstitutionalizing issue mootness; the arguments for recognizing mootness as prudential apply uniquely to personal stake mootness. This is true both of the theoretical argument advanced above, in Part II.A, and of the descriptive argument offered in Part II.B. The theoretical argument-that the established prudential exceptions to the mootness bar cannot be reconciled with the constitutional model of mootness-has no application to issue mootness, because the three major exceptions discussed herein are solely applicable in cases of personal stake mootness. This is because each of the exceptions depends on a reasonable likelihood of recurrence, ${ }^{266}$ while an issue moot case is, by definition, one that raises an issue with no reasonable likelihood of recurrence as to anyone. Similarly, the descriptive argument-that in circumstances where prudential factors strongly favor hearing a case courts distort the elements of the exceptions as necessary to justify hearing the case-also pertains principally to personal stake mootness, because an issue moot case is unlikely to present a compelling argument for immediate resolution under the prudential factors discussed above, in Part III.B. ${ }^{267}$

266 None of the exceptions can apply absent some sufficient likelihood of recurrence. The capable of repetition, yet evading review exception can be applied only if the issue is reasonably likely to recur. S. Pac. Terminal Co. v. Interstate Commerce Comm'n, 219 U.S. 498, 515 (1911). Similarly, the class action exception depends on a reasonable likelihood of recurrence as to some other member of the class that plaintiff seeks to represent. Sosna v. Iowa, 419 U.S. 393, 402 (1975). Finally, the voluntary cessation exception also depends on the likelihood of recurrence, as it bars dismissal based on defendant's cessation of the challenged activity, unless defendant shows that it is "absolutely certain" that the wrong cannot be expected to recur. See Friends of the Earth, Inc. v. Laidlaw Envtl. Servs., Inc., 528 U.S. 167, 189 (2000). In a case that is "issue moot," the defendant will presumably have little difficulty establishing the requisite degree of certainty.

267 Although there are many instances in which courts have distorted doctrine to justify hearing personal stake moot cases, see supra Part II.B, I am not aware of any circumstance in which a court has bent the doctrine in order to justify hearing an issue moot case. Nor does such an occurrence seem likely. In a case raising an issue that is not reasonably likely to recur, at least two of the prudential factors are quite unlikely to weigh in favor of hearing the case. There will be no special urgency to prompt resolution as the issue is not affecting third parties and is not reasonably expected to do so. See supra Part III.B.2. Moreover, the interest in efficiently using judicial resources will generally counsel against deciding an issue that is unlikely to recur. See supra Part III.B.4. 
Second, one of the principal normative arguments offered by defenders of the Constitutional model of justiciability doctrines-the argument that justiciability doctrines protect the separation of powersapplies far more strongly to issue mootness than to personal stake mootness. In his famous article The Doctrine of Standing as an Essential Element of the Separation of Powers, ${ }^{268}$ then-Judge Scalia argued that standing serves the function of confining courts to the enforcement of individual rights, rather than the generalized interest in having the political branches comply with the law:

[T] he law of standing roughly restricts courts to their traditional undemocratic role of protecting individuals and minorities against impositions of the majority, and excludes them from the even more undemocratic role of prescribing how the other two branches should function in order to serve the interest of the majority itself. 269

This separation of powers argument has some force with respect to issue mootness, inasmuch as to permit a litigant to seek relief for an issue moot claim is to permit that plaintiff to assert a claim that no other private individual could assert. A litigant's assertion of a personal stake moot claim, in contrast, does not involve delegation of the executive branch's law enforcement authority, but only of a private individual's enforcement right. The Supreme Court has repeatedly recognized the significance of this distinction between issue and person in terms of whether deeming a case justiciable raises separation of powers concerns. ${ }^{270}$

Finally, there is also a compelling practical argument for my more incremental approach to deconstitutionalizing mootness: it can be adopted by lower federal courts based on existing precedent. Because the paradigm of mootness offered in this Article is implicit in much of the mootness case law, the explicit adoption of a prudential conception of personal stake mootness can be justified as a reinterpretation

268 Antonin Scalia, The Doctrine of Standing as an Essential Element of the Separation of Powers, 17 Suffolk U. L. Rev. 881 (1983).

269 Id. at 894 (emphasis in original).

270 See Flast v. Cohen, 392 U.S. 83, 100-01 (1968) ("The question whether a particular person is a proper party to maintain the action does not, by its own force, raise separation of powers problems related to improper judicial interference in areas committed to other branches of the Federal Government. Such problems arise, if at all, only from the substantive issues the individual seeks to have adjudicated."); see also Allen v. Wright, 468 U.S. 737, 751 (1984) (referring to "the general prohibition on a litigant's raising another person's legal rights" as a selfimposed limitation on the exercise of jurisdiction by federal courts, and not part of the "core component [of standing] derived directly from the Constitution"). 
of existing precedent, ${ }^{271}$ rather than a wholesale abandonment or "transformation" of it. ${ }^{272}$ In contrast, previous scholarly proposals to deconstitutionalize mootness in its entirety are likely foreclosed by precedent and thus could be adopted only by the Supreme Court. 273

Rather than abandon the constitutional model of mootness, courts should adopt a more sensible interpretation of Article III-one implicit in much of the mootness case law-that holds that what the Constitution requires is a live issue. Whether the plaintiff is the correct person to assert a claim based on that issue should be recognized as a prudential matter. This conception of Article III's relevance to mootness analysis mirrors the interpretation that courts apply in resolving third-party standing issues, and the reasons for recognizing the distinction between issue and person in the standing context have at least equal weight in the context of mootness.

\section{Conclusion}

The conventional understanding of mootness as a constitutional bar to federal court jurisdiction is a doctrine at war with itself. The judicially developed exceptions to the mootness doctrine cannot be

271 For a thoughtful critique of this methodology of judicial decisionmaking, coupled with an acknowledgement of its prevalence, see Michael C. Dorf, Dicta and Article III, 142 U. PA. L. REV. 1997, 2024-40 (1994).

272 The overwhelming number of federal cases stating that mootness is a jurisdictional bar derived from Article III is not fatal to this argument for three reasons. First, many of those cases involved issue mootness, and thus can properly be regarded as limited to that context. Second, a great many of those cases apply a mootness exception, and thus decline to dismiss the case. Musings on the nature of the mootness bar in cases declining to apply it are properly regarded as dicta as they arguably do not "actually decide" the nature of the mootness bar, and do not lead to the result in the case. See Michael Abramowicz \& Maxwell Stearns, Defining Dicta, 57 STAN. L. Rev. 953, 961 (2005) ("A holding consists of those propositions along the chosen decisional path or paths of reasoning that (1) are actually decided, (2) are based upon the facts of the case, and (3) lead to the judgment. If not a holding, a proposition stated in a case counts as dicta."). And third, even in the set of cases that describe mootness as a jurisdictional bar and then proceed to dismiss, it is very often the case that the prudential factors would not have supported hearing the case in any event, and thus, that a court applying an explicitly prudential doctrine of mootness wouid aisu hâve disminssed. In these cases, as well, the court's musings on the nature of the mootness bar as jurisdictional or prudential are arguably dicta, inasmuch as they are unnecessary to the result. See Black's Law Dictionary 1102 (8th ed. 2004) (defining "obiter dictum" as "[a] judicial comment made while delivering a judicial opinion, but one that is unnecessary to the decision in the case and therefore not precedential (although it may be considered persuasive)"). Ultimately, the authority regarding the jurisdictional or prudential nature of personal stake mootness is equivocal. There is Supreme Court and Court of Appeals authority for both models, which leaves room for the possibility of reinterpretation of existing precedent by lower courts.

273 See Lee, supra note 11, at 605 (suggesting that Supreme Court action would be necessary to "transform" mootness from a constitutional doctrine into a prudential doctrine). 
reconciled with the constitutional account of mootness, and case law reveals that courts regularly apply mootness, not as a mandatory bar on jurisdiction, but as a prudential doctrine. This disconnect between the rhetoric and reality of mootness doctrine creates confusion for litigants and courts, makes it difficult for litigants to predict results, and invites cynicism about results-oriented decisionmaking.

To resolve this confusion, this Article has developed an alternative paradigm for mootness, based on the recognition that "mootness" refers to two quite distinct doctrines-a constitutional core, which bars federal jurisdiction for cases where the issue is moot, and a larger, prudential curtilage, applicable when the plaintiff's personal stake in the outcome has become moot. This partially prudential model of mootness avoids many of the difficulties inherent in previous scholarly efforts to untether mootness from Article III, and offers three principal advantages over the discredited constitutional model: (1) it is theoretically coherent; (2) it better explains the results in a wide range of difficult mootness cases, and thus has more predictive power; and (3) by bringing personal stake in the mootness context into alignment with third-party standing doctrine, it represents a step in the direction of a more unified theoretical approach to issues of justiciability. 